\title{
Can movable PCM-filled TES units be used to improve the performance of PV panels? Overview and experimental case-study
}

\author{
N. Soares ${ }^{1,2^{*}}$, J.J. Costa ${ }^{1}$, A.R. Gaspar ${ }^{1}$, T. Matias ${ }^{3}$, P.N. Simões ${ }^{3}$, L. Durães ${ }^{3}$ \\ ${ }^{1}$ ADAI, LAETA, Department of Mechanical Engineering, University of Coimbra, Coimbra, Portugal \\ ${ }^{2}$ ISISE, Department of Civil Engineering, University of Coimbra, Coimbra, Portugal \\ ${ }^{3}$ CIEPQPF, Department of Chemical Engineering, University of Coimbra, Coimbra, Portugal \\ *Correspondent author: Nelson Soares, nelson.soares@dem.uc.pt
}

\begin{abstract}
This paper provides an overview on how phase change materials (PCMs) can be used for the thermal regulation of photovoltaic $(P V)$ devices, and describes an experimental apparatus to assess whether the performance of $250 \mathrm{~W}$ STC-rated commercial polycrystalline silicon PV panels can be improved by placing movable thermal energy storage (TES) units filled with the free-form PCM RT 22 HC on the panels' back. The outdoor apparatus is located at Coimbra, Portugal. Three identical PV panels were separately installed and individually monitored: one panel was taken as reference; the other two were considered together with a TES unit each with horizontally and vertically oriented cavities, $P V / P C M_{1}$ and $P V / P C M_{2}$ systems, respectively. The time evolutions of the temperature of the PV panels were compared with each other to analyse the possible thermal regulation potential of the TES units. The time evolution of the power output was also assessed to compare the efficiency of the different systems. Finally, the energy produced per day by each system was evaluated. The results showed that the PV operating temperature has increased ca. $16-21^{\circ} \mathrm{C}$ and $14-18{ }^{\circ} \mathrm{C}$ in the $P V / P C M_{1}$ and $P V / P C M_{2}$ systems, respectively, in comparison with the reference $P V$ panel (at peak time). Moreover, the daily energy produced by the $P V$ panel of the PV/PCM $M_{1}$ and $\mathrm{PV} / \mathrm{PCM}_{2}$ systems was, respectively, 3.3-6.5\% and 3.3-6.0\% lower than that produced by the reference $P V$ panel during the measured short-term summer operation period. Therefore, it was concluded that the movable TES units have a negative impact on the performance of the PV/PCM systems, and that a PCM with a higher phase change temperature must be chosen for Mediterranean climate.
\end{abstract}

Keywords: Photovoltaic performance, phase change material, PV/PCM system, temperature regulation, outdoor experiment

\section{Introduction}

As reported by the International Renewable Energy Agency (IRENA) [1] and discussed by Soares 
et al. [2], the present global installed solar PV capacity makes a significant contribution to the renewable energy sources installed capacity, growing at a faster rate than the wind capacity in the last years. Sathe and Dhoble [3] also foresee a huge demand for PV solar cells in the near future in order to achieve the prospect of the International Energy Agency (IEA) of 16\% share of PV in total energy production by 2050 . According to these authors, about $80-85 \%$ of solar cells market is based on crystalline silicon solar cells [3]. However, polycrystalline silicon PV devices may experience high operating temperatures, which reduces the efficiency of solar to electrical energy conversion in the PV cells, as well as the lifespan of these systems.

Several passive and active strategies have been proposed to mitigate overheating of PV devices and to prevent resulting power loss, including thermoelectric cooling [4], [5], natural or forced air ventilation [4-9], hydraulic or refrigerant cooling [4-10], heat pipe cooling [4-10], and the use of PCMs [4-17]. Shah and Ali [18] further highlighted the use of mono-nanofluids or hybrid/binary nanofluids for cooling of PV modules. Some authors pointed out that active heat dissipation techniques typically need pumps or fans, which can increase power consumption and system maintenance costs [11], [19]. However, in comparison with passive techniques, active cooling usually enhances heat dissipation rates, leading to higher PV performances. Passive techniques can also have a significant capital cost. For example, if the additional PCM material cost is taken into account [20], the use of PCMs for some PV applications may not be cost-effective in comparison with other active approaches. Nižetić et al. [13] argued that PCM-based passive cooling techniques could only be an option in the future if a significant PCM material price drop occurs. Nevertheless, as suggested by Ma et al. [11], if the thermal energy through temperature regulation can be used for other purposes, or directly used in the building, some techniques can become more cost-effective by offsetting some of the capital cost. In spite of the questionable long-term economic feasibility of passive PCM-based technologies for the thermal management of PV systems, the assessment of the technical viability of this sort of cooling approach in laboratory conditions or outdoor real-scale pilot test facilities is fundamental to promote the technology. As highlighted by Islam et al. [17], PCM-based cooling brings some positive features (e.g. PV temperature regulation, high heat absorption rate in a small quantity of material, no moving parts, no electricity consumption, and no maintenance cost) that should be further evaluated.

PCMs undergo melting/solidification in a temperature range known a priori, becoming very suitable for thermal management and TES applications [21]. However, as stated by Qureshi et al. [22], the low thermal conductivity of PCMs may result in slow heat transfer and low heat storage and release rate, which can be a major drawback for practical applications. Previous works have experimentally shown that the containment of free-form PCMs in fin-enhanced aluminium 
containers is a good method to simultaneously solve the problem of liquid-leakage and improve the heat transfer to the PCM-bulk [23], [24], overcoming the problem of PCMs' low thermal conductivity. The term "free-form" means that the liquid PCM can freely move inside the container due to natural convection [25]. These kinds of TES units can then be used in the design of new TES systems for buildings (e.g. PCM-enhanced bricks [26], [27] and PCM-shutters [28]), and for the thermal regulation of PV systems (see refs. [29-32]), which can contribute to promote the design of new PV/PCM and PCM-enhanced building-integrated photovoltaic (BIPV) systems - BIPV/PCM systems. Several authors have also proposed the use of TES units as heat sinks for the thermal management of electronics (see refs. [33-36]).

This study aims at assessing if movable TES units filled with a paraffin-based free-form PCM (with a phase change transition temperature around $22^{\circ} \mathrm{C}$ ) can be used for the temperature regulation of commercial polycrystalline silicon PV panels during summer in Mediterranean climate (dry warm summer). It also aims at identifying the key design features that must be taken into account in the design of a PV/PCM system to improve solar to electrical energy conversion efficiency through temperature regulation of the PV cells. In fact, this work targets the development of a real-scale outdoor experimental apparatus to: (i) evaluate the potential PCM-based thermoregulation effect on commercial polycrystalline silicon PV panels; (ii) evaluate the efficiency of PV/PCM systems incorporating TES units filled with the free-form PCM (RT 22 HC provided by Rubitherm ${ }^{\circledR}$ Technologies GmbH); (iii) carry out an experimental parametric study to evaluate the influence of two different configurations of the TES unit (metallic container with horizontally and vertically oriented cavities) on the performance of the system; (iv) provide reliable experimental results for benchmarking and numerical validation purposes.

\section{Literature review}

A PV/PCM system is defined as a hybrid technology integrating PV panels and PCMs into a single module to achieve higher solar to electrical energy conversion efficiency through temperature regulation of the PV cells. In a PCM-enhanced PV thermal system (PV/T/PCM system), a thermal collector is further considered to absorb the stored heat in the PCM [37-40]. When temperature increases, the PCM changes its phase from solid to liquid, absorbing latent heat over a narrow range of transition temperatures and preventing the temperature rise in the PV cells. Some authors claim that the transition temperature of the PCM should be as low as possible for maximum performance [9], while others state that melting temperatures greater than $30^{\circ} \mathrm{C}$ appear to be more promising to control the temperature rise of the PV panel during a longer period in comparison with low melting temperatures [15]. For Chandel and Agarwal [15], PCMs with solid-liquid phase change 
temperature lower than $25^{\circ} \mathrm{C}$ may become ineffective after peak insolation hours (when the PCM mass is completely melted) and face problems regarding the complete solidification of the PCM during hot summer nights. This problem was also remarked by Browne et al. [12], according to whom few studies were carried out considering extended periods of time in order to properly evaluate the issue of re-solidification - if the PCM is not fully discharged during the night, it will not be able to fulfil its maximum storage capacity the following day. Smith et al. [41] developed a global analysis for determining the increase in the annual energy output attained by a PV system with an integrated PCM layer. They were particularly interested at finding the optimal melting-peak temperature, $T_{\mathrm{m}}$, of the PCM for several locations. The results showed that PCM-enhanced cooling is most beneficial in regions with higher insolation and lower intra-annual climate variability. When, for a specific location, the climatic conditions significantly vary throughout the year, a particular optimum transition temperature of the PCM cannot be set for the whole year [17]. Therefore, the development of movable TES units filled with different PCMs (to act as heat sinks), that can be replaced in the PV/PCM system (placed on the PV panels' back) throughout the year (considering a possible optimal $T_{\mathrm{m}}$-value for each season) can be seen as a way to promote PV cooling with PCMs. This research gap can be seen as a new field of research, and this study aims to provide some results that show that the phase change temperature range of the PCM to be integrated in these kinds of PV/PCM systems must be correctly chosen as a function of the local climate and the season under evaluation, as an erroneous choice may have a negative impact in the overall performance of the PV panel.

In the last years, several small-scale numerical and experimental studies have been carried out to evaluate how PCMs can be used in PV/PCM systems [19], [29-32], [42]. These studies addressed several issues such as: $(i)$ the importance of validating numerical predictions against realistic experimental results; (ii) the influence of the PCM container geometry and material in the heat transfer with solid-liquid phase change; (iii) the influence of adding high-conductivity material fins to accelerate phase change transitions; (iv) the impact of the shape, thickness and number of fins; (v) the importance of natural convection in the melted PCM domain; (vi) the role of the type and quantity of PCM used; and (vii) the influence of the main thermophysical properties of the PCM chosen to fill up the containers, particularly the phase change transition temperature range and the thermal conductivity.

Hasan et al. [43] developed an experimental apparatus to assess the influence of the thermal mass of the PCM and the thermal conductivity of both the PCM and the overall PV/PCM system on the thermal regulation performance of small-scale PV/PCM systems with polycrystalline silicon PV cells. The parametric study was performed considering: ( $i$ ) five PCMs with different $T_{\mathrm{m}}$-values $(c a$. 
$\left.25 \pm 4{ }^{\circ} \mathrm{C}\right)$, thermal conductivities $\left(c a .0 .14-1.09 \mathrm{~W} \mathrm{~m}^{-1}{ }^{\circ} \mathrm{C}^{-1}\right)$ and latent heat of fusion $(c a .140-213$ $\mathrm{kJ} \mathrm{kg}^{-1}$ ); (ii) four configurations of the PV/PCM system combining different container materials (aluminium or perspex), two container widths and two thicknesses for the external wall; and (iii) three insolation intensities $\left(500,750\right.$ and $\left.1000 \mathrm{~W} \mathrm{~m}^{-2}\right)$ for an ambient temperature of $20 \pm 1^{\circ} \mathrm{C}$. The results showed that a maximum temperature reduction of $10{ }^{\circ} \mathrm{C}$ was maintained at the PV front for 5 hours at a $1000 \mathrm{~W} \mathrm{~m}^{-2}$ insolation. Hasan et al. [44] scaled up the previous cell scale approach to the panels size and they developed an outdoor real-scale experimental apparatus to evaluate the temperature regulation of PV/PCM systems in two different climates: Dublin (Ireland), and Vehari (Pakistan). Two PCMs were used in the experiments: a eutectic mixture of capric acid - palmitic acid and a salt hydrate with $T_{\mathrm{m}}$-values of $22.5{ }^{\circ} \mathrm{C}$ and $29.8{ }^{\circ} \mathrm{C}$, respectively. Three $65 \mathrm{~W}$ polycrystalline EVA encapsulated PV panels were used: one PV without any PCM was taken as reference; the other two were each attached at the back with a metallic internally finned PCM-filled rectangular container. The results showed that both PCMs attained higher temperature drop of the PV panel in the warm and stable weather conditions of Vehari than in the cooler and variant conditions of Dublin. Moreover, the PCM with higher $T_{\mathrm{m}}$-value achieved a higher temperature drop and power savings at both sites. In fact, a temperature drop of $10^{\circ} \mathrm{C}$ and $21{ }^{\circ} \mathrm{C}$, and associated power savings of $5.1 \%$ and $13 \%$ were attained in Dublin and Vehari, respectively. In another study, Hasan et al. [45] further evaluated the energy and economic viability of the PV/PCM systems for both climates, and they concluded that they are not cost effective in Ireland. On the other hand, the results showed that such systems are financially viable for hot climates like Pakistan.

Hasan et al. [46] carried out a yearly-based evaluation of the energy performance of a PV/PCM system for the extremely hot environmental conditions of Al Ain, United Arab Emirates. The numerical model used in the predictions was validated against experimental results. Two small polycrystalline EVA-encapsulated PV panels were tested outdoors: one PV panel without PCMs was treated as reference; to the other, an internally finned metallic container filled with the paraffin based PCM RT 42 (melting range of $38-43^{\circ} \mathrm{C}$ ) was added to the panel's back. The results showed that the PCM eventually caused a $10.5{ }^{\circ} \mathrm{C}$ drop on average in PV temperature (at peak time), resulting in 5.9\% increase in PV power output on yearly basis. Moreover, the PV/PCM system was found to exhibit consistent performance for most of the time, but the PCM produced less cooling in peak cool and peak hot months attributed to its incomplete melting and solidification, respectively. Hasan et al. [47] used the same PV/PCM system and a small test chamber to experimentally evaluate the impact of the PCM on the electrical and thermal energy efficiency of the PV and of the indoor space, considering the same hot climatic conditions of Al Ain, United Arab Emirates. In the experimental apparatus, the PV/PCM system was fixed at the front of the test chamber as a 
BIPV/PCM system. The results showed an increase in PV power output of $7.2 \%$ at peak and 5\% on average along with enhanced indoors cooling effect of $9.5 \%$ at peak and $7 \%$ on daytime average. Hachem et al. [48] also developed an outdoor experimental setup to assess the energy performance of a PV/PCM system in hot climatic conditions. The experiments were performed in Al-Khyara, West Bekaa of Lebanon, considering three prototypes: (i) a standalone small-scale PV panel; (ii) a PV panel with a container of pure PCM (white petroleum jelly with melting temperature range of $36-60{ }^{\circ} \mathrm{C}$ and thermal conductivity of $0.18 \mathrm{~W} \mathrm{~m}^{-1}{ }^{\circ} \mathrm{C}^{-1}$ ) on the panel's back; (iii) a PV panel with a container of combined PCM (white petroleum jelly enhanced with copper and graphite, with melting temperature range of $36-60{ }^{\circ} \mathrm{C}$ and thermal conductivity of $91 \mathrm{~W} \mathrm{~m}^{-1}{ }^{\circ} \mathrm{C}^{-1}$ ) added at the rear face of the PV panel. The results showed the great importance of a higher thermal conductivity of the PCM to improve PV cooling. Moreover, it was shown that the electrical efficiency of the PV panels increased $3 \%$ and $5.8 \%$ on average when using the pure PCM and the combined PCM, respectively. Another outdoor experimental setup was developed by Stropnik and Stritih [49] in Ljubljana, Slovenia. In this study, a PV panel was improved by placing a PCM layer on the panel's back. The commercial PCM RT $28 \mathrm{HC}$ with $\left(T_{\mathrm{m}}=28^{\circ} \mathrm{C}\right)$ was considered. The experimental results showed that the PV cell temperature of the PV/PCM system was lower by a maximum of $35.6{ }^{\circ} \mathrm{C}$ compared to the reference PV panel without the PCM, for a period of one day. The experimental results were also used to validate a TRNSYS based simulation model. The numerical results showed that the annual increase of electric energy production and energy generation efficiency was about $7.3 \%$ and $0.8 \%$, respectively, compared to the conventional PV panel.

Tan et al. [50] evaluated the influence of different inner configurations of the metallic container (different number of fins) to be filled with the commercial PCM RT $27\left(T_{\mathrm{m}}=27^{\circ} \mathrm{C}\right)$ and to be coupled to the rear side of the PV panel, in order to passively achieve cooling of the PV cells. Ciulla et al. [51] developed a simple one-dimensional finite difference numerical model to evaluate the behaviour of PV/PCM systems. The numerical results were compared with real data obtained from an outdoor test facility located in Palermo, Italy: two identical silicon PV panels were used and one of which was coupled to the PCM (melting range of $26-28^{\circ} \mathrm{C}$ ). The PCM was encapsulated in a double package of plastic bag. Lo Brano et al. [52], [53] used the same apparatus to provide further experimental data for the validation of an explicit finite difference formulation of energy balance of the crystalline PV/PCM system. Kibria et al. [54] also developed a transient onedimensional energy balance model to assess the thermal performance of PV/PCM systems. A finite difference scheme was applied to discretize the energy balance equation, while a fully implicit scheme was used to discretize the heat balance in the PCM module. Three PCMs $\left(T_{\mathrm{m}}\right.$ of 21,25 and $28^{\circ} \mathrm{C}$ ) were considered in the simulations. The authors used previous experimental results provided 
by Hasan et al. [43] to validate the numerical approach. The numerical results showed that PCMs could enhance the efficiency of the PV module up to 5\%. However, more efforts should be carried out to match numerical and experimental results, e.g. the natural convection in the melted PCM must be considered in the simulations. In fact, Kant et al. [55] stated that for realistic simulation of heat and mass transfer in PV/PCM systems, it is also crucial to take into account the following features: $(i)$ the convection effect within the melted PCM, (ii) the inclination angle of the PV panel, and (iii) the velocity of wind.

It can be remarked that more studies should be conducted bearing in mind $(i)$ different year round climatic conditions in order to evaluate the suitability of PCMs with different melting-peak temperatures for diverse geographical locations; (ii) the need to enhance the heat transfer into the PCM and between the PV panel and the PCM; (iii) the importance of the efficient night-time resolidification of the PCM and the need to improve the heat extraction from the PCM, and (iv) the need to optimize the quantity of PCM for a specific PV/PCM/climate application. These studies shall consider both short and long-term periods of time in the numerical, laboratory and outdoor real-scale approaches. According to Nižetić et al. [13], there is still a great lack of field-based studies to evaluate the improvement of the energy performance of PV/PCM systems, as numerical and laboratory based studies are mostly presented. Moreover, according to Ma et al. [11] the outlook for future research in the field of PV/PCM systems can be grouped into seven areas: $(i)$ system configuration development and optimization; (ii) materials selection; (iii) experimental measurements, performance evaluation and demonstration; (iv) thermal energy extraction and regulation; $(v)$ heat transfer enhancement; (vi) mathematical model development; and (vii) life cycle assessment on economic feasibility and environmental benefits. This paper aims to contribute for the advancement of the first five listed areas of research.

\section{Methodology}

\subsection{Thermophysical characterization of the PCM}

Several parameters were considered for the selection of the PCM, such as the values of the main thermophysical properties of the PCM provided by the manufacturer, the compatibility of the paraffin-based product with the material of the container, its price, the standard lead-time and delivery terms. The thermophysical characterization of commercial PCMs is critical since data provided by manufacturers can be insufficient or uncertain. In this work, (i) the latent heat of fusion and solidification, (ii) the specific heat of both solid and liquid phases, and (iii) the melting and solidification temperatures of the PCM were determined by Modulated Differential Scanning Calorimetry (MDSC), using a Q100 model MDSC equipment from TA Instruments; (iv) the thermal 
conductivity of the solid and liquid phases was measured using the Transient Plane Source (TPS) method - Hot Disk TPS $2500 \mathrm{~S}$ equipment. The heat flow and heat capacity measurements were calibrated at $2{ }^{\circ} \mathrm{C} \min ^{-1}$ using indium and sapphire as standards, respectively. A modulation period of $120 \mathrm{~s}$ and a temperature amplitude of $\pm 1{ }^{\circ} \mathrm{C}$ were applied in the modulated mode. Both standard and PCM samples were analysed in aluminium pans with aluminium lids. A dry nitrogen purge flow rate of $50 \mathrm{~mL} \mathrm{~min}{ }^{-1}$ was applied in both calibration and measurements. Two PCM samples of $6.38 \mathrm{mg}$ and $7.27 \mathrm{mg}$ were analysed, and two heating/cooling cycles were performed for each one of the samples to check for repeatability. The thermal responses of the samples were measured with an underlying heating/cooling rate of $0.5^{\circ} \mathrm{C} \mathrm{min}^{-1}$, in the temperature range of $-20{ }^{\circ} \mathrm{C}$ to $40{ }^{\circ} \mathrm{C}$. The thermal conductivity was measured in the $0-50{ }^{\circ} \mathrm{C}$ range, with an increment of $5{ }^{\circ} \mathrm{C}$. Moreover, four measurements were performed at each temperature to check for repeatability.

\subsection{Experimental setup and instrumentation}

Fig. 1 provides a 3D sketch of the experimental setup used to evaluate the performance of a set of three identical 250 W STC-rated Risen RSM60-6-250P commercial polycrystalline silicon PV panels under the same environmental conditions. The main parameters of the PV panels under standard test condition (STC) are presented in Table 1. The PV modules were deployed outdoors in Coimbra, Portugal $(40.19 \mathrm{~N}, 8.42 \mathrm{~W})$, with a $30^{\circ}$ tilt angle facing south. The PV panels were separately installed and individually monitored: one of the panels shall be taken as reference for every experiment, $\mathrm{PV}_{\text {ref }}$; the other two were considered together with a TES unit each, forming new PV/PCM systems (Fig. 1). In fact, each PV/PCM system is formed by a movable TES unit filled with the commercial free-form paraffin-based PCM RT 22 HC placed on the panel's back (Fig. 2).

Two configurations of the TES unit were considered in the experiments: a $21.17 \mathrm{~kg}$ (empty) $1580 \mathrm{~mm} \times 922 \mathrm{~mm} \times 25 \mathrm{~mm}$ aluminium container with 35 horizontally oriented rectangular cavities (Fig. 3b) to be used in the PV/PCM ${ }_{1}$ system; and a $21.32 \mathrm{~kg}$ (empty) $1580 \mathrm{~mm} \times 930 \mathrm{~mm} \times$ $25 \mathrm{~mm}$ aluminium container with 19 vertically oriented rectangular cavities (Fig. 3a) to be used in the PV/PCM 2 system. Since the PCM RT 22 HC shows a volume expansion of about $12.5 \%$ during phase change transitions [56], a small air space was left on the top of each cavity to accommodate volume variations. The TES units were filled up with the PCM in the liquid phase: $26.08 \mathrm{dm}^{3}$ and $27.27 \mathrm{dm}^{3}$ of liquid PCM were used, respectively, to fill up the TES unit with vertically and horizontally oriented cavities. Afterwards, every small opening used to fill each cavity were protected with a rubber cap and sealed with epoxy adhesive to prevent liquid leakage (Fig. 2).

Before the assembly of the PV/PCM systems, the TES units were pre-cooled at $10^{\circ} \mathrm{C}$ to guarantee that the PCM volume was completely solidified before starting the experiments. For this 
purpose, the refrigerated room described in ref. [57] was used for the pre-cooling of the TES units (the TES units were left in the refrigerated room at $10{ }^{\circ} \mathrm{C}$ during seven days). The assembly of the PV/PCM systems and the placement of the temperature and heat flux sensors were carried out during the night to minimise the swift heating of the TES units before starting recording. In the PV/PCM assembly, a thin film of thermal grease and a thin creased aluminium sheet were considered in-between the PV panel and the TES unit to minimize the thermal contact resistance in the interface area and to maximize heat transfer.

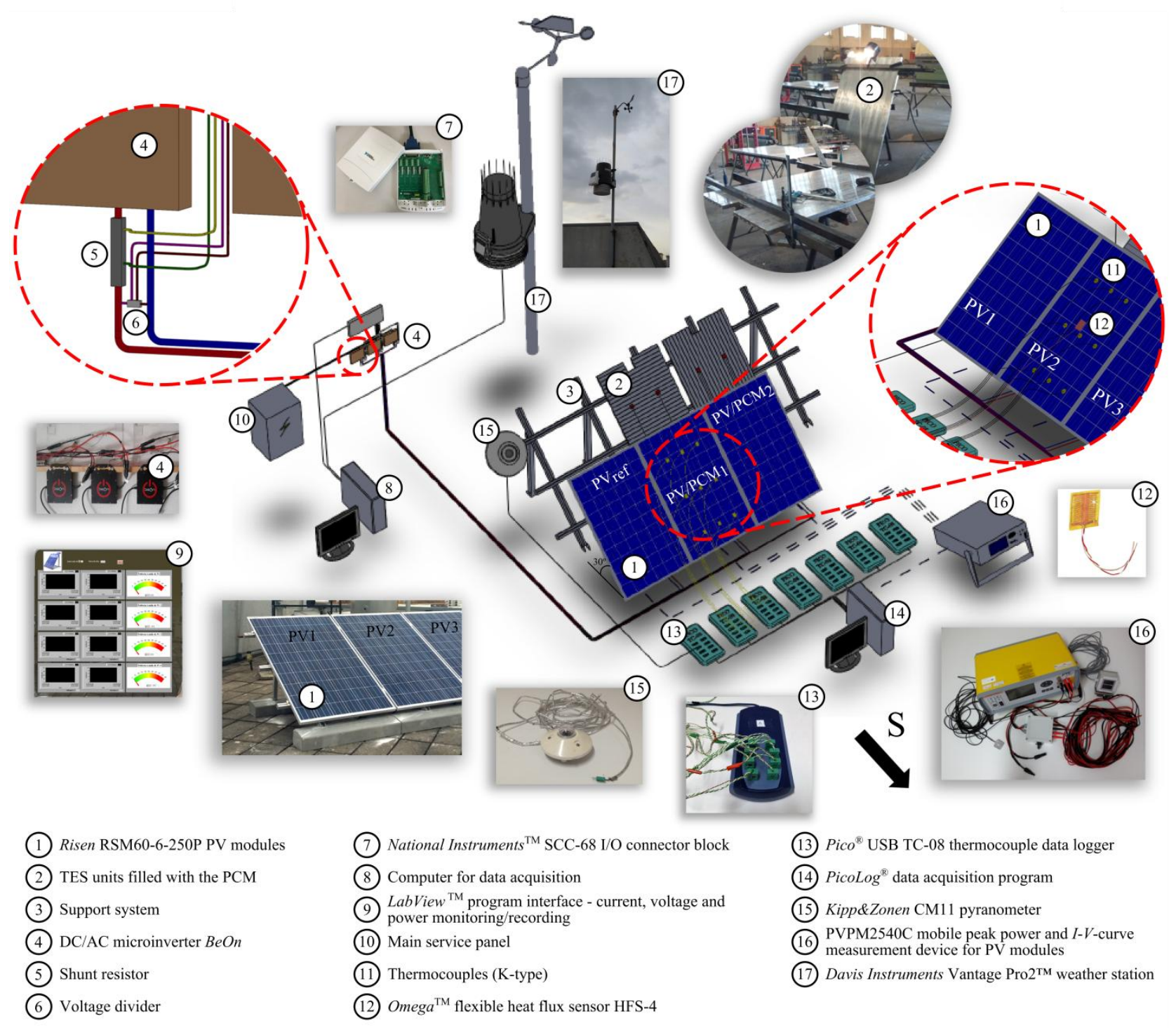

Fig. 1. Sketch of the experimental apparatus with the main equipment/instrumentation used.

The time evolutions of the temperature of the PV panels were compared with each other to analyse the effective thermal regulation potential of the TES units. 90 calibrated thermocouples (K-type) were used in the experiments: nine thermocouples, coupled three by three in parallel, were equally placed on the front and rear surfaces of each PV panel (54 sensors were used); nine thermocouples 
were evenly distributed on the front and back surfaces of each TES unit (36 sensors were used), respectively, for measuring the temperature transient evolution on each surface (Fig. 4). The thermocouples were calibrated all together, connected to the respective Pico ${ }^{\circledR}$ TC-08 data logger (accuracy for temperature - sum of $\pm 0.2 \%$ of reading and $\pm 0.5^{\circ} \mathrm{C}$; accuracy for voltage - sum of \pm $0.2 \%$ of reading and $\pm 10 \mu \mathrm{V}$ ), using the calibration bath Heto Lab Equipment DBT KB21 (accuracy of $\pm 0.1^{\circ} \mathrm{C}$ ) equipped with the HetoTherm DBT 200 thermostat and a PT100 probe. The calibration was carried out from $5{ }^{\circ} \mathrm{C}$ to $65^{\circ} \mathrm{C}$, considering steps of $5{ }^{\circ} \mathrm{C}$. Once all the measurements have been taken, the linear least-squares curve-fitting method was used to fit a line to the recorded data for each group of thermocouples. The $R$-square value was higher than 0.999 for all the calculated regression lines.

Table 1. Risen RSM60-6-250P PV module STC parameters: irradiance $1000 \mathrm{~W} \mathrm{~m}^{-2}$, cell temperature $25^{\circ} \mathrm{C}$ and air mass AM 1.5 according to EN 60904-3 [58].

\begin{tabular}{lr}
\hline Peak power, $P_{\mathrm{pk}}[\mathrm{W}]$ & 250 \\
Open-circuit voltage, $V_{\mathrm{OC}}[\mathrm{V}]$ & 37.4 \\
Short-circuit current, $I_{\mathrm{SC}}[\mathrm{A}]$ & 8.88 \\
Maximum power voltage, $V_{\mathrm{MPP}}[\mathrm{V}]$ & 30.0 \\
Maximum power current, $I_{\mathrm{MPP}}[\mathrm{A}]$ & 8.34 \\
Module efficiency [\%] & 15.3 \\
Fill factor, $F F[$ ] & 0.753 \\
Dimensions $($ height $\times$ width $\times$ depth $)(\mathrm{mm})$ & $1650 \times 992 \times 35$ \\
\hline
\end{tabular}

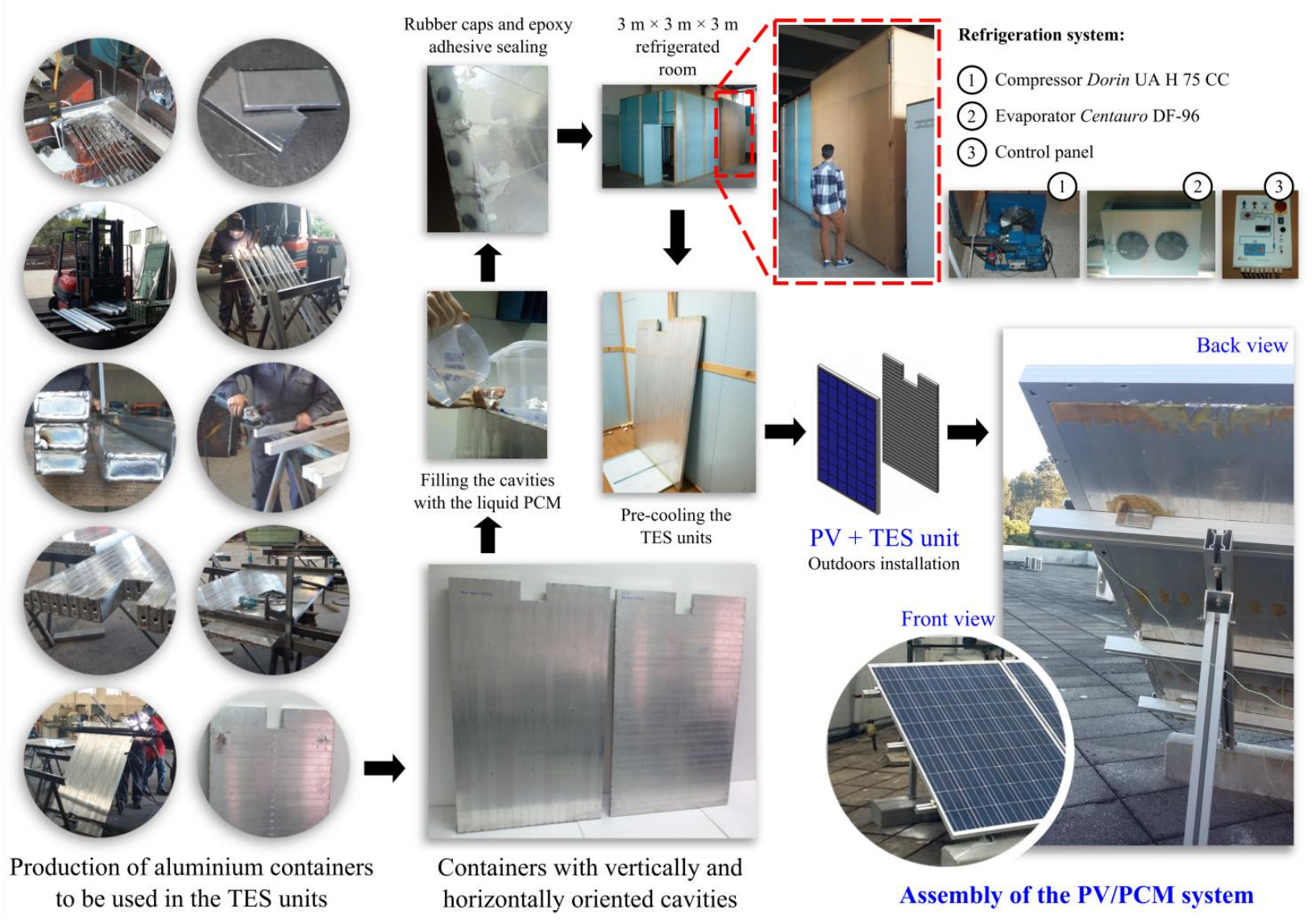

Fig. 2. Experimental procedure for the assembly of the PV/PCM systems. 


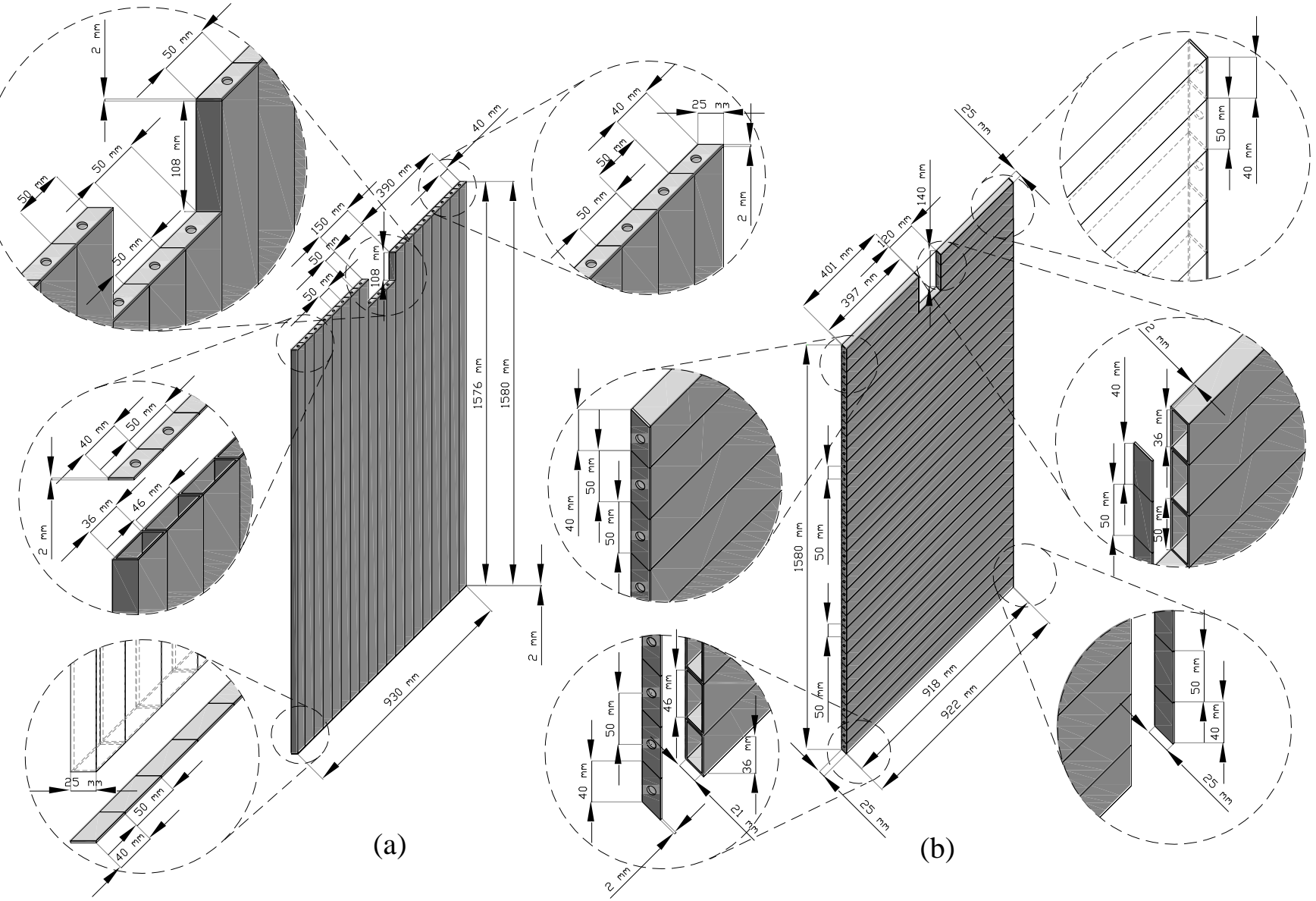

Fig. 3. 3D sketch of the aluminium container (a) with 19 vertically oriented rectangular cavities to be used in the $\mathrm{PV} / \mathrm{PCM}_{2}$ system; (b) with 35 horizontally oriented rectangular cavities to be used in the $\mathrm{PV} / \mathrm{PCM}_{1}$ system.

Thermocouple (K-type) Omega $a^{\circledR}$ thin film flux sensors HFS-4

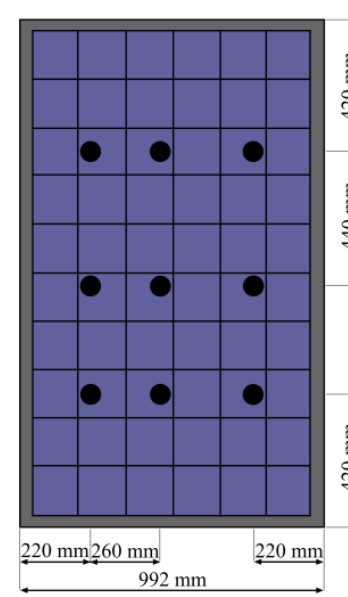

(a)

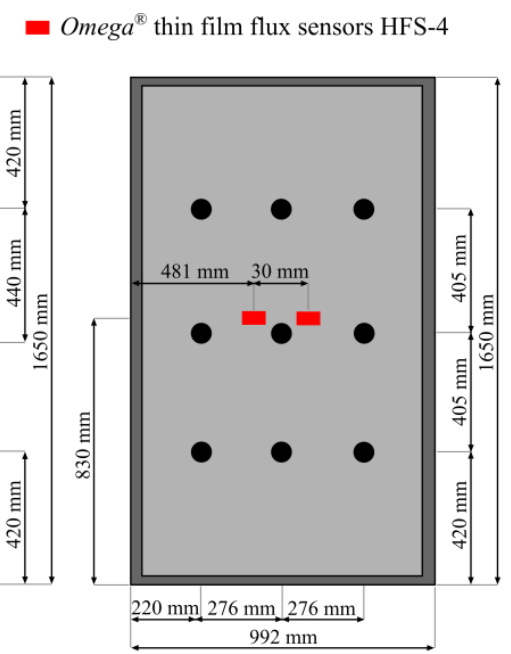

(b)

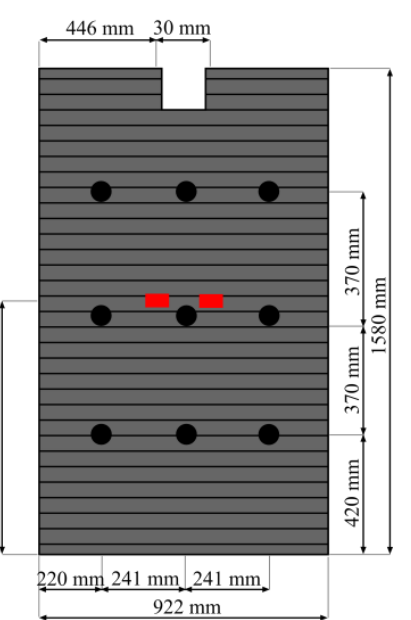

(c)

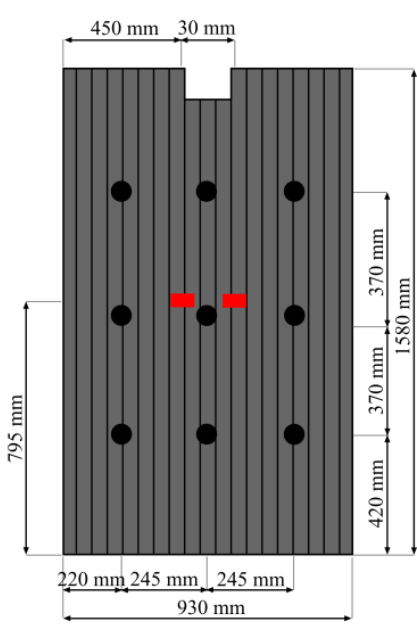

(d)

Fig. 4. Sketch of the distribution of the thermocouples and the heat flux meters on the: (a) front surface of the PV panels; (b) rear surface of the PV panels; (c) front and back surfaces of the TES unit with horizontally oriented cavities; (c) front and back surfaces of the TES unit with vertically oriented cavities. (Not to scale).

To measure the time evolution of the heat flux on the rear surfaces of the PV panels, and on the 
front and back surfaces of each TES unit, 14 Omega ${ }^{\circledR}$ thin film flux sensors HFS-4 were used (connected to the Pico ${ }^{\circledR}$ TC-08 data loggers): two heat flux meters were distributed on each surface (Fig. 5). A Kipp\&Zonen CM11 pyranometer (accuracy of $\pm 3 \%$ of the reading) was connected to a Pico $^{\circledR}$ TC-08 data logger to directly measure the solar irradiance on the PV panels' plane. The temperatures, heat fluxes and solar irradiance data acquisition system was composed by several Pico ${ }^{\circledR}$ TC-08 data loggers connected to a computer and controlled by the PicoLog ${ }^{\circledR}$ data acquisition program. Data from all sensors were collected and stored at $10 \mathrm{~s}$ intervals. A Davis Instruments Vantage Pro $2^{\mathrm{TM}}$ weather station installed next to the experimental apparatus was also used to provide further information about the local weather conditions during the experiments. It collected and stored data (e.g. air temperature, dew point temperature, humidity, wind speed, wind direction, pressure, etc.) at $5 \mathrm{~min}$ intervals. All the measured data were provided online in the website of the weather station [59].

The time evolution of the power output of each PV module, $P_{\mathrm{PV}}$, was also evaluated to compare the efficiency of the different systems. The solar conversion efficiency, $\eta$, calculated at each instant, $i$, represents the percentage of available energy from the sun that gets converted into electricity accordingly to Eq. (1), considering the $1.638 \mathrm{~m}^{2}$ area of the PV panel, $A . G_{\text {pyra }}$ is the solar irradiance on the PV panels' plane measured with the Kipp\&Zonen CM11 pyranometer.

$$
\eta_{i}=\frac{P_{\mathrm{PV}_{i}}}{A \times G_{\mathrm{pyra}}} \times 100 \%
$$

The monitoring and data acquisition system was composed by a National Instruments ${ }^{\mathrm{TM}}$ SCC-68 I/O connector block connected to a LabView ${ }^{\mathrm{TM}}$ developed program. Fig. 5 shows the electrical setup considered for each PV panel: it was composed by a voltage divider and a $0.05 \Omega$ resistor for the acquisition of voltage and DC current data, respectively, plus a DC/AC microinverter BeOn. Data were collected and stored at $10 \mathrm{~s}$ intervals. Finally, a PVPM2540C mobile peak power measuring device and $I-V$-curve tracer for PV modules was used to measure the main parameters of the three PV panels deployed in the outdoor experimental setup before the assembly of the PV/PCM systems.
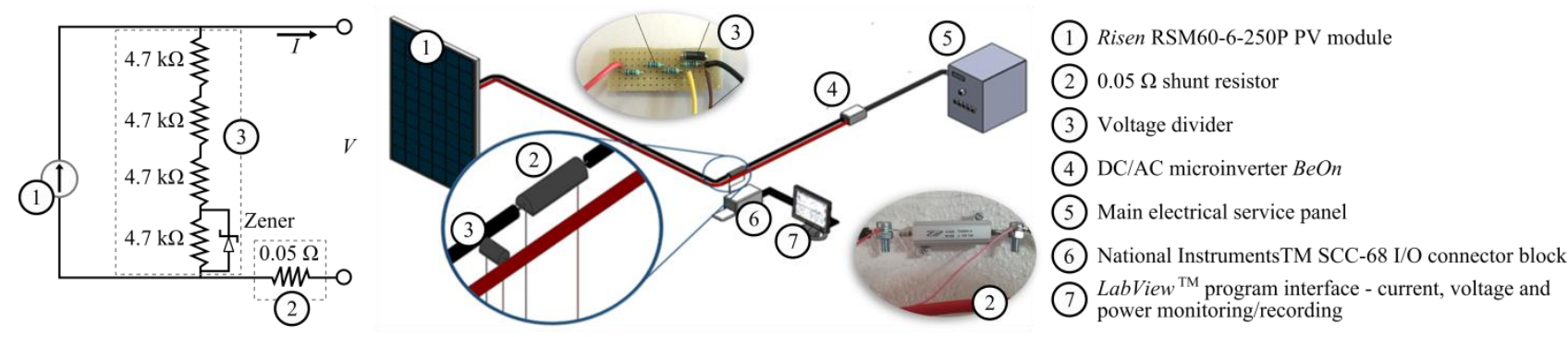

Fig. 5. Sketch of the electrical setup considered for each PV panel. 


\subsection{Calibration and preliminary experiments}

Some exploratory experiments were performed before the assembly of the PV/PCM systems to evaluate the reliability of the measurement of the solar irradiance on the PV panels' plane with the Kipp\&Zonen CM11 pyranometer connected to a Pico ${ }^{\circledR}$ TC-08 data logger, $G_{\text {pyra. The solar }}$ irradiance on an horizontal plan was firstly measured with the pyranometer during a sunny day, and the results were then compared with the values of the solar irradiance measured with the Davis Instruments Vantage Pro $2^{\mathrm{TM}}$ weather station installed close to the experimental apparatus, $G_{\mathrm{ws}}$. The solar irradiance on the PV panels' plane was also measured with the PVPM2540C mobile device, $G_{\mathrm{PVPM}}$, during sunny clear sky conditions. The obtained results were then compared with the values measured with the Kipp\&Zonen CM11 pyranometer.

Another exploratory test was carried out during a sunny day with the PVPM2540C mobile peak power measuring device and $I$ - $V$-curve tracer to evaluate the consistency of the three PV modules. The PVPM2540C device enables the measurement of the peak power, $P_{\mathrm{pk}}$, of a PV module under environmental conditions in a very simple and fast way (the measuring device converts the measured values into STC conditions afterwards), and the prompt definition of the $I-V$ curve of the verified PV module, allowing the in situ verification of the electrical characteristics of the PV panel. Besides measuring $I_{\mathrm{SC}}$ and $V_{\mathrm{OC}}$ values, this mobile device estimates the voltage and current at the maximum power point (MPP), $V_{\mathrm{MPP}}$ and $I_{\mathrm{MPP}}$, respectively. These values are used to determine the fill factor, $F F$, of the PV panel according to Eq. (2).

$$
F F=\frac{V_{\mathrm{MPP}} \times I_{\mathrm{MPP}}}{I_{\mathrm{SC}} \times V_{\mathrm{OC}}}
$$

The time evolution of the power output of each PV module was also evaluated during three consecutive days, in order to evaluate the daily energy generated by each PV panel, $E$, and to verify the consistency of the three PV modules. The energy generated by each PV was calculated by integrating over time the measured evolution of the power output for each module.

\subsection{Monitoring the PV/PCM systems performance}

The reference and the PV/PCM systems were monitored during five consecutive summer days (from 14th to 18th August, 2018) in order to assess the performance of the three systems. The following parameters were evaluated during the short-term operation period: $(i)$ time evolution of the temperature of the PV cells of each system; (ii) thermal regulation potential of the TES units; (iii) solar conversion efficiency of each PV panel; (iv) daily energy generated by each PV panel. 


\section{Results and discussion}

\subsection{Measurement of the main thermophysical properties of the PCM}

The measured thermophysical properties of the PCM RT $22 \mathrm{HC}$ were compared with the properties listed in the datasheet of the material, as shown in Table 2. Fig. 6 shows the DSC signal and temperature plots during the heating and cooling ramps. The measured values of $T_{\mathrm{m}}$ and $T_{\mathrm{s}}$ are reasonably consistent with the temperatures provided by Rubitherm ${ }^{\circledR}$. The product datasheet of the PCM does not specify the latent heat of fusion/solidification of the material. In fact, only a heat storage capacity of $190 \pm 14.3 \mathrm{~kJ} \mathrm{~kg}^{-1}$ in the $14-29{ }^{\circ} \mathrm{C}$ temperature range is provided. The measurements provided different values of $L_{\mathrm{m}}$ and $L_{\mathrm{s}}$ of $c a .104 \mathrm{~kJ} \mathrm{~kg}^{-1}$ and $98 \mathrm{~kJ} \mathrm{~kg}^{-1}$, respectively. These values are much lower than those expected from the product datasheet. The same problem was remarked by Fořt et al. [60]. Regarding the specific heat, only a single value of $2000 \mathrm{~J} \mathrm{~kg}^{-1} \mathrm{~K}^{-1}$ is provided by the manufacturer. In the present work, different values of $c_{\mathrm{p}}$ were measured for the solid and liquid phases. These values are lower than the $c_{\mathrm{p}}$-value provided by the datasheet of the material (Table 2), mainly for the liquid phase. Fig. 7 shows the variation of the effective heat capacity, $c_{\text {eff, }}$ with temperature for the heating and cooling processes of the PCM. The datasheet of the PCM only provides a single value of $0.2 \mathrm{~W} \mathrm{~m}^{-1} \mathrm{~K}^{-1}$ for the thermal conductivity of the material. However, the present results (Fig. 8) show that a larger $k$-value was obtained for the liquid phase, of ca. $0.3 \mathrm{~W} \mathrm{~m}^{-1} \mathrm{~K}^{-1}$.

Table 2. Main thermophysical properties of the PCM RT $22 \mathrm{HC}$ used in the experiments.

\begin{tabular}{|c|c|c|}
\hline & Measured values & Data from manufacturer [56] \\
\hline Melting-peak temperature, $T_{\mathrm{m}}\left({ }^{\circ} \mathrm{C}\right)$ & $22.4 \pm 0.2$ & 22 \\
\hline Solidification peak temperature, $T_{\mathrm{s}}\left({ }^{\circ} \mathrm{C}\right)$ & $22.2 \pm 0.2$ & 22 \\
\hline Heat storage capacity $\pm 7.5 \%\left[14-29^{\circ} \mathrm{C}\right]\left(\mathrm{kJ} \mathrm{kg}^{-1}\right)$ & - & 190 \\
\hline \multicolumn{3}{|l|}{ Latent heat $\left[10-30^{\circ} \mathrm{C}\right]\left(\mathrm{kJ} \mathrm{kg}^{-1}\right)$} \\
\hline - Melting, $L_{\mathrm{m}}$ & $103.6 \pm 3.5$ & - \\
\hline $\begin{array}{l}\text { - Solidification, } L_{\mathrm{S}} \\
\text { Snecific heaf }\left(\mathrm{K} \mathrm{kg}^{-1} \mathrm{~K}^{-1}\right)\end{array}$ & $99.3 \pm 1.3$ & - \\
\hline \multicolumn{3}{|l|}{ Specific heat $\left(\mathrm{J} \mathrm{kg}^{-1} \mathrm{~K}^{-1}\right)$} \\
\hline - Solid, $c_{\mathrm{ps}}\left(\right.$ at $\left.10^{\circ} \mathrm{C}\right)$ & $1806 \pm 0.4$ & 2000 \\
\hline $\begin{array}{l}- \text { Liquid, } c_{\mathrm{pl}}\left(\text { at } 30^{\circ} \mathrm{C}\right) \\
\end{array}$ & $968 \pm 0.3$ & 2000 \\
\hline \multicolumn{3}{|l|}{ Thermal conductivity $\left(\mathrm{W} \mathrm{m}^{-1} \mathrm{~K}^{-1}\right)$} \\
\hline - Solid, $k_{\mathrm{s}}$ & $0.20 \pm 0.01$ & 0.20 \\
\hline - Liquid, $k_{1}$ & $0.26 \pm 0.00$ & 0.20 \\
\hline \multicolumn{3}{|l|}{ Density, $\rho\left(\mathrm{kg} \mathrm{m}^{-3}\right)$} \\
\hline - Solid, $\rho_{\mathrm{s}}\left(\right.$ at $\left.20^{\circ} \mathrm{C}\right)$ & 0.79 & 0.76 \\
\hline - Liquid, $\rho_{1}\left(\right.$ at $\left.50^{\circ} \mathrm{C}\right)$ & 0.76 & 0.70 \\
\hline Volume expansion (\%) & - & 12.5 \\
\hline
\end{tabular}




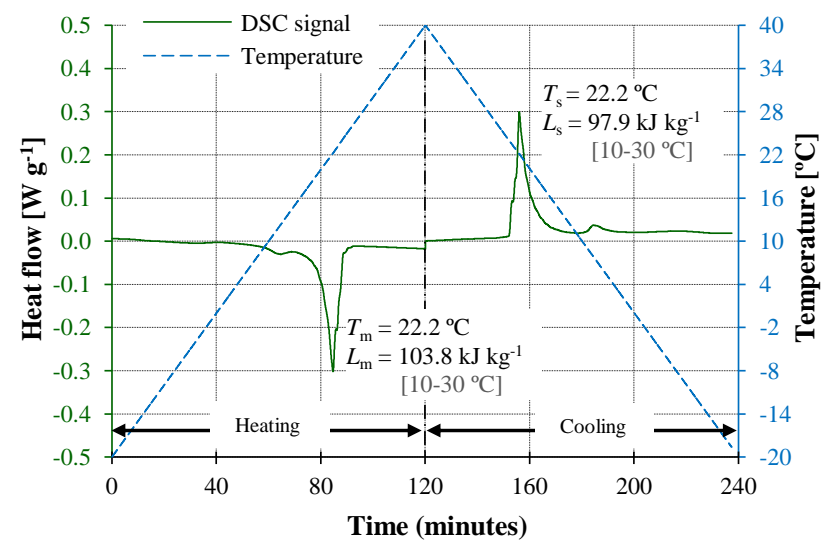

Fig. 6. DSC curve for the $6.38 \mathrm{mg}$ sample of the PCM RT $22 \mathrm{HC}$. Measurements with the Q100 model MDSC equipment in the temperature range of $-20^{\circ} \mathrm{C}$ to $40^{\circ} \mathrm{C}$ (underlying heating/cooling rates of $0.5^{\circ} \mathrm{C} \mathrm{min}{ }^{-1}$ ).

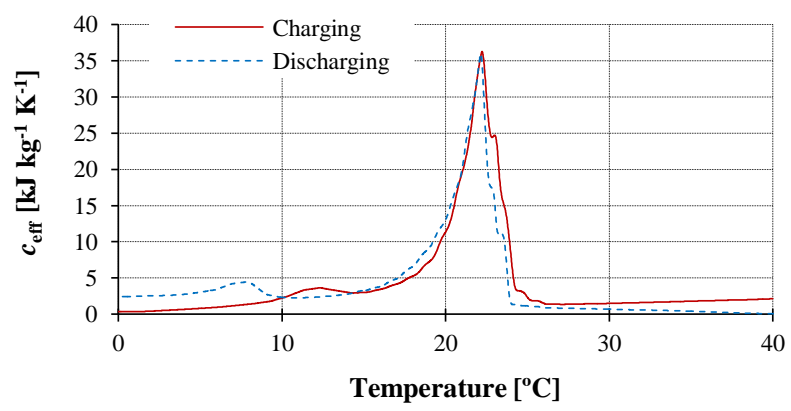

Fig. 7. Evolution of the effective heat capacity with temperature, $c_{\text {eff }}(T)$, for heating and cooling of the $6.38 \mathrm{mg}$ PCM sample. Measurements with the Q100 model MDSC equipment (underlying heating/cooling rates of $0.5^{\circ} \mathrm{C} \mathrm{min}^{-1}$ ).

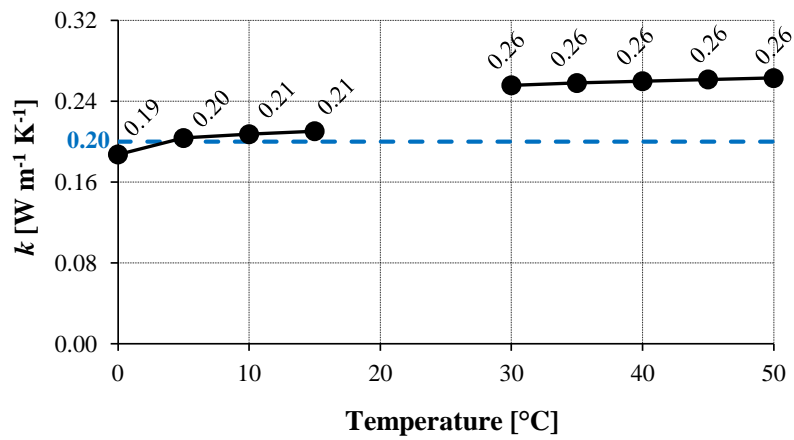

Fig. 8. Variation of the thermal conductivity with temperature, $k(T)$ - measurements with the Hot Disk TPS $2500 \mathrm{~S}$ equipment in the $0-50^{\circ} \mathrm{C}$ temperature range. The dashed line indicates the $k$-value given by the manufacturer of PCM RT $22 \mathrm{HC}$.

\subsection{Preliminary measurements}

Fig. 9 shows the results of the exploratory test carried out to evaluate the reliability of measuring solar irradiance with the Kipp\&Zonen CM11 pyranometer. The measurements with the Davis Instruments Vantage Pro $2^{\mathrm{TM}}$ weather station installed next to the experimental apparatus were taken as reference. Comparing the $G_{\text {pyra }}$ and $G_{\mathrm{ws}}$ profiles, they generally show similar trend. The local 
drop on the $G_{\text {pyra }}$ curve around 3:15 PM may have been caused by a bird that have alighted on the equipment. Fig. 10 shows the results of the other exploratory test performed to assess the truthfulness of the Kipp\&Zonen CM11 pyranometer measurements. This time, the solar irradiance was measured on the PV panels' plane ( $30^{\circ}$ tilt angle facing south) with both the pyranometer and the PVPM2540C mobile device. The measurements were performed on July 17, 2018, from 3:33 PM to 4:13 PM. The results obtained with the two devices show a similar trend with a maximum deviation of $c a .2 \%$. The obtained results have shown that the Kipp\&Zonen CM11 pyranometer can be used for directly measuring the solar irradiance on the PV panels' plan.

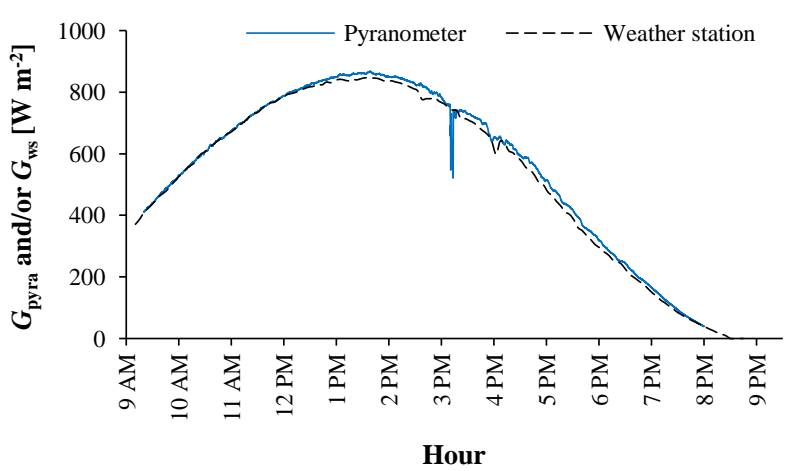

Fig. 9. Solar irradiance on an horizontal plan measured with the Kipp\&Zonen CM11 pyranometer, $G_{\text {pyra }}$, and the Davis Instruments Vantage Pro $2^{\mathrm{TM}}$ weather station, $G_{\mathrm{ws}}$. Measurements carried out on August 2, 2018.

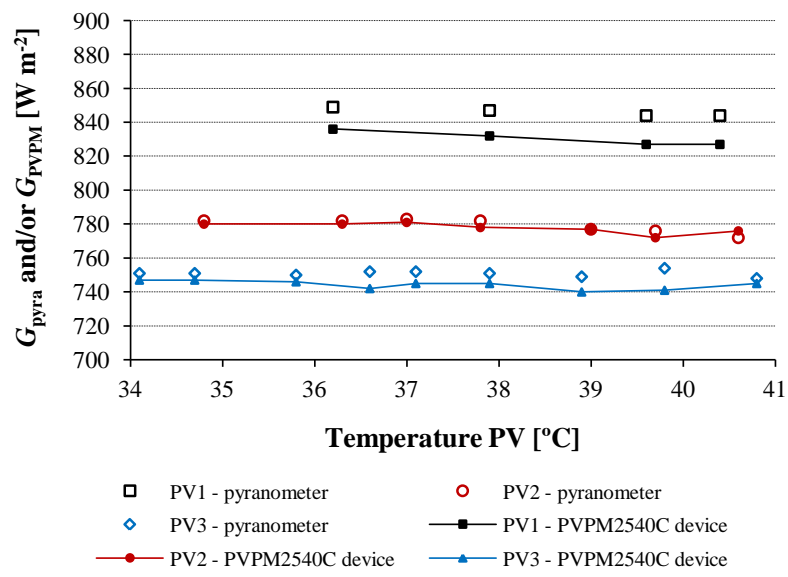

Fig. 10. Solar irradiance on the PV panels' plane ( $30^{\circ}$ tilt angle facing south) measured with the Kipp\&Zonen CM11 pyranometer, $G_{\text {pyra }}$, and the PVPM2540C mobile device, $G_{\mathrm{PVPM}}$. Measurements carried out on July 17, 2018, from 3:33 PM to $4: 13$ PM.

Fig. 11 shows the results of the exploratory test carried out with the PVPM2540C device to evaluate the consistency of the three PV modules with each other, and with the parameters of the PV module provided by the supplier [58] (Table 1). The measurements were carried out on July 17, 2018, from 3:33 PM to 4:13 PM. Considering the $P_{\mathrm{pk}}$-value of $250 \mathrm{~W}$ provided by the supplier and the $P_{\mathrm{pk}}$ 
results obtained for the three PV panels under environmental conditions, a maximum error of $c a$ 3.4\% was attained (for the PV1 panel). Therefore, the peak power parameter provided in the datasheet of the PV module was verified for the three PV panels. The maximum power for each measurement, $P_{\mathrm{MPP}}$, was determined via Ohm's law using the measured values of $I_{\mathrm{MPP}}$ and $V_{\mathrm{MPP}}$.

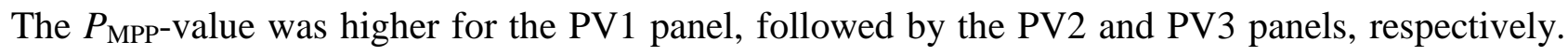
This trend was caused by the variation of the solar irradiance during the experiments, and the order on which the PV panels were tested. The measurements started at 3:33 PM with the PV1 panel under a solar irradiance of $836 \mathrm{~W} \mathrm{~m}^{-2}$, and finished at 4:13 PM with the PV3 panel under a solar irradiance of $745 \mathrm{~W} \mathrm{~m}^{-2}$. This $91 \mathrm{~W} \mathrm{~m}^{-2}$ difference between the first and the last measurements gives the explanation for the difference in the $P_{\text {MPP }}$ results, since the current mostly depends on solar irradiance. On the other hand, voltage mainly depends on the temperature of the PV cells. Therefore $V_{\text {MPP }}$ was higher for lower temperatures of the PV cells at the beginning of the experiments with each PV panel. Indeed, as the temperature of the PV cells increases, $V_{\text {MPP }}$ decreases and, consequently, $P_{\mathrm{MPP}}$ decreases too. The results for the $I_{\mathrm{SC}}$ and $V_{\mathrm{OC}}$ values follow the same trend, as $I_{\mathrm{SC}}$ mainly depends on solar irradiance, and $V_{\mathrm{OC}}$ on the temperature of the PV cells. The $F F$-value obtained for each $\mathrm{PV}$ was in good agreement with the $F F$-value presented in the datasheet of the PV. In fact, a maximum deviation of $c a 1.5 \%$ was obtained for the PV1 panel.
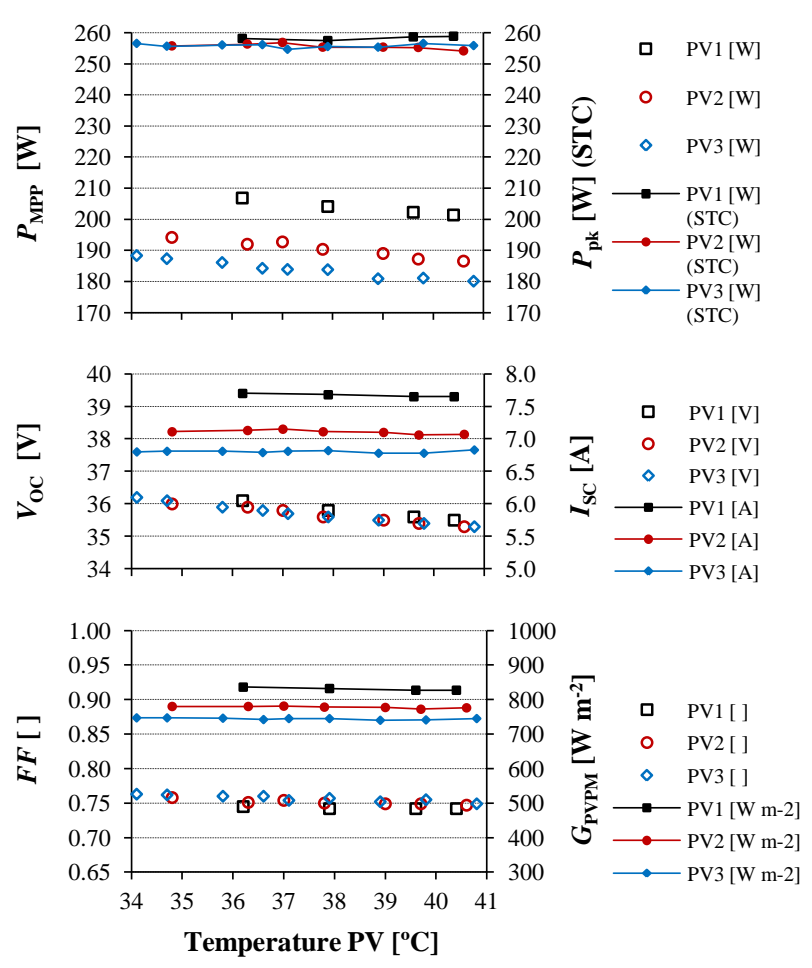

Fig. 11. Results of the exploratory test carried out with the PVPM $2540 \mathrm{C}$ mobile peak power measuring device and $I-V$ curve tracer to evaluate the consistency of the three PV modules. Measurements carried out on July 17, 2018, from 3:33 PM to 4:13 PM. 
Fig. 12 shows the energy generated by each PV panel during the three evaluated days (from $19^{\text {th }}$ to $21^{\text {st }}$ May, 2018). The results reveal good consistency in the production of energy by the three PV modules, with a maximum deviation of $\mathrm{ca} 4 \%$ in the second day (considering the energy generated by the PV2 panel in comparison with the energy generated by the PV1 panel taken as reference).

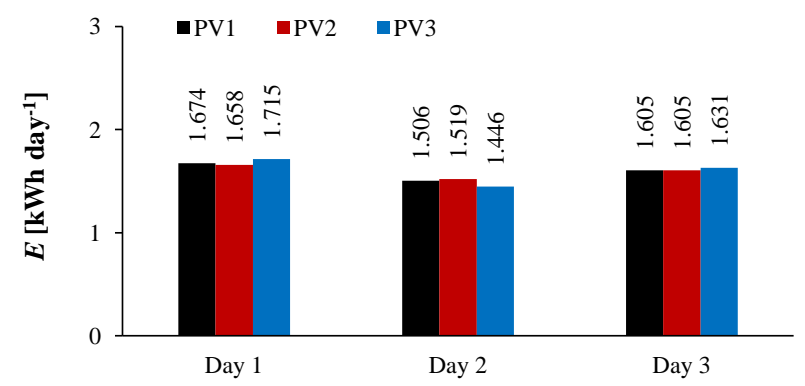

Fig. 12. kWh generated per day by each PV panel from $19^{\text {th }}$ to $21^{\text {st }}$ May, 2018.

\subsection{Performance of the PV/PCM systems}

Fig. 13 shows the time evolutions of the outdoor temperature and the solar irradiance on the PV panels' plane that were registered during the five consecutive summer days considered to evaluate the performance of the PV/PCM systems (from $14^{\text {th }}$ to $18^{\text {th }}$ August, 2018). It also shows the time evolutions of the temperature of the PV cells and the solar conversion efficiency of each PV panel obtained during the same short-term operation period.

The results clearly evidence that the temperature of the PV cells increases during the peak hours (when the solar irradiance and the outdoor air temperature are higher), which reduces the solar conversion efficiency of the PV panels. It can also be observed that the temperature rise in the PV cells of the PV/PCM systems is significantly higher than the temperature rise in the PV cells of the reference PV panel (PV1). In fact, the PV operating temperature has increased $c a .16-21^{\circ} \mathrm{C}$ and ${ }^{14}-18^{\circ} \mathrm{C}$ in the PV2 and PV3, respectively, in comparison with the $\mathrm{PV}_{\text {ref }}$ (at peak time). This boost in the operating temperature caused by the assembly of the TES units filled with the PCM on the panels' back reduces the daily energy produced by the PV panels of the PV/PCM systems as shown in Fig. 14. Indeed, the kWh generated per day by the PV panels of the PV/PCM 1 and $\mathrm{PV} / \mathrm{PCM}_{2}$ systems was, respectively, 3.3-6.5\% and 3.3-6.0\% lower than that produced by the $\mathrm{PV}_{\text {ref. }}$. 

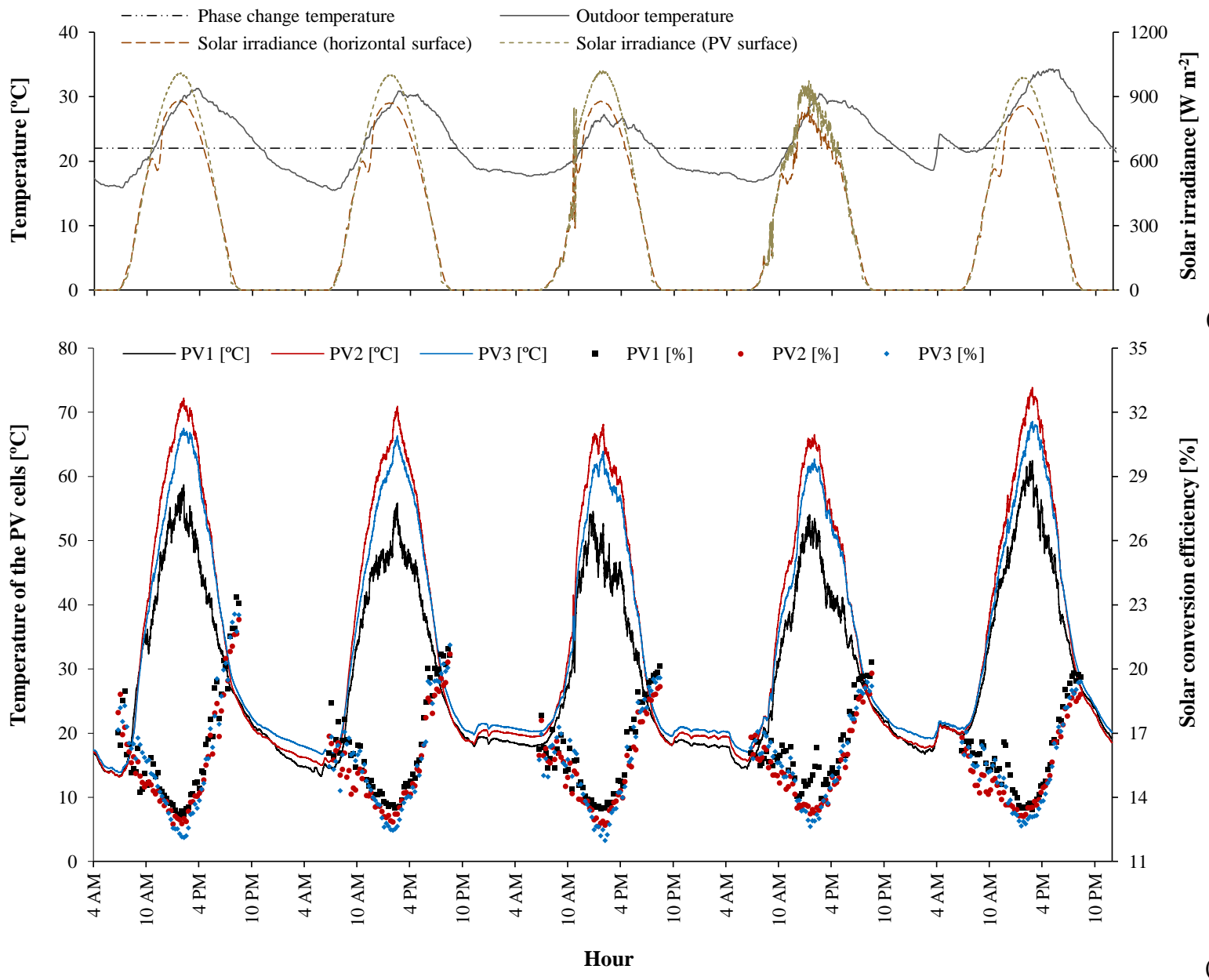

(a)

Fig. 13. (a) Time evolution of the main climatic conditions measured from $14^{\text {th }}$ to $18^{\text {th }}$ August, 2018; (b) time evolutions of the temperature of the PV cells and of the solar conversion efficiency of each PV panel obtained for the same shortterm summer period. The dashed line indicates the melting-peak temperature of the PCM RT 22 HC provided by the manufacturer.

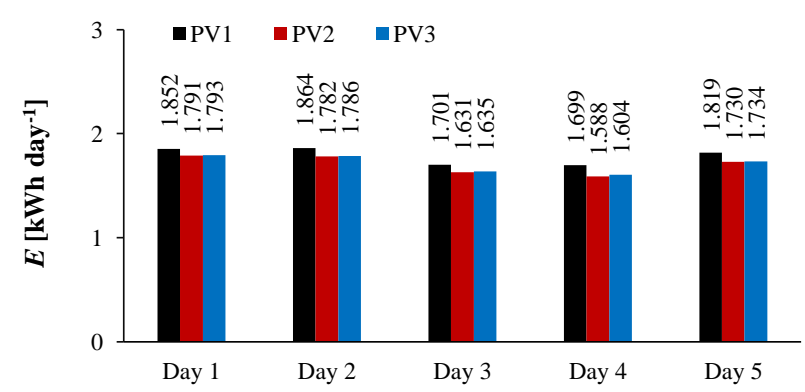

Fig. 14. $\mathrm{kWh}$ generated per day by each PV panel from $14^{\text {th }}$ to $18^{\text {th }}$ August, 2018.

These results evidence that the TES units filled with the PCM RT 22 HC did not shave the peak temperatures of the PV panels of the PV/PCM systems as desired. In fact, they show that the TES units have a negative impact in the overall performance of the PV panels, as wind cooling in the $\mathrm{PV}_{\text {ref }}$ is much more efficient during peak hours. Several reasons may justify these results:

(i) the quantity of PCM within the TES units may not be enough to guaranty a longer thermal 
regulation period of the PV cells during charging, as the PCM volume is melting very fast during the first hours of the day;

(ii) the melting-peak temperature of the PCM is too low, leading to the fast melting of the PCM during the first hours of the day, and to the resulting short thermal regulation period;

(iii) the presence of a very thin air-layer in-between the PV panels and the TES units of the PV/PCM systems in the experimental assembly adds an extra thermal resistance, which may reduce the heat transfer between the rear surface of the PV panels and the TES units; moreover, as this thin air-layer is not ventilated, the temperature rise of the air may also contribute to the temperature rise of the temperature in the PV cells;

(iv) the assembly of the TES units on the rear faces of the PV panels blocks the wind cooling effect; therefore, after completely melting the PCM volume, the temperatures of the heat storage modules and the air in-between the PV panels and the TES units will significantly increase, as wind cooling in the flat rear surface of the TES unit is not as efficient as desired, in spite of the metallic fins considered at the heart of the PCM;

(v) the low melting-peak temperature of the PCM, combined with the low thermal conductivity of the material and the flat surface configuration of the rear faces of the TES units can make the solidification process of the PCM during the night difficult; moreover, the TES units act as heat sources during the night, and at the beginning of the next charging process (first hours of the next day), the temperature of the PV cells of the PV/PCM systems will be higher than the temperature of the reference PV cells (wind cooling system).

Fig. 15 shows all the recorded values obtained during the first two days of the experiments (14 ${ }^{\text {th }}$ and $15^{\text {th }}$ August, 2018). Heat flux is considered positive from top to bottom direction, i.e., from the front surface of the PV panel to the rear surface of the TES unit. The results show that the heat flux on the rear surface of the PV1 ( $\left.\mathrm{PV}_{\text {ref }}\right)$ is higher from $1 \mathrm{PM}$ to $4 \mathrm{PM}$, during which the temperature of the PV cells is higher. After this period, the temperature of the PV cells and the heat flux on the rear surface of the $\mathrm{PV}_{\text {ref }}$ start decreasing as both solar irradiance on the panel's plane and outdoor air temperature start decreasing (Fig. 15c), while wind speed starts increasing (Fig. 15a). On the other hand, the peak heat flux on the rear surfaces of the PV2 and PV3 panels occurs earlier due to the melting process of the PCM, which also delays the peak temperature recorded in the PV cells of the PV2 and PV3 as latent heat is being stored in the TES unit. Overnight, more precisely between 7 PM and 8.30 AM, the heat flux in the rear surfaces of the PV2 and PV3 panels is negative, since the thermal energy stored in the TES unit during the day is being discharged (solidification of the PCM). During this period, the temperature of the PV cells of the $\mathrm{PV}_{\text {ref }}$ is lower due to wind cooling on both surfaces of the panel. The time evolutions of the heat flux measured on 
the front surfaces of the TES units follow the same trends as those of the heat flux measured on the back surfaces of the PV2 and PV3 panels. Nevertheless, the day and night peak values are higher.
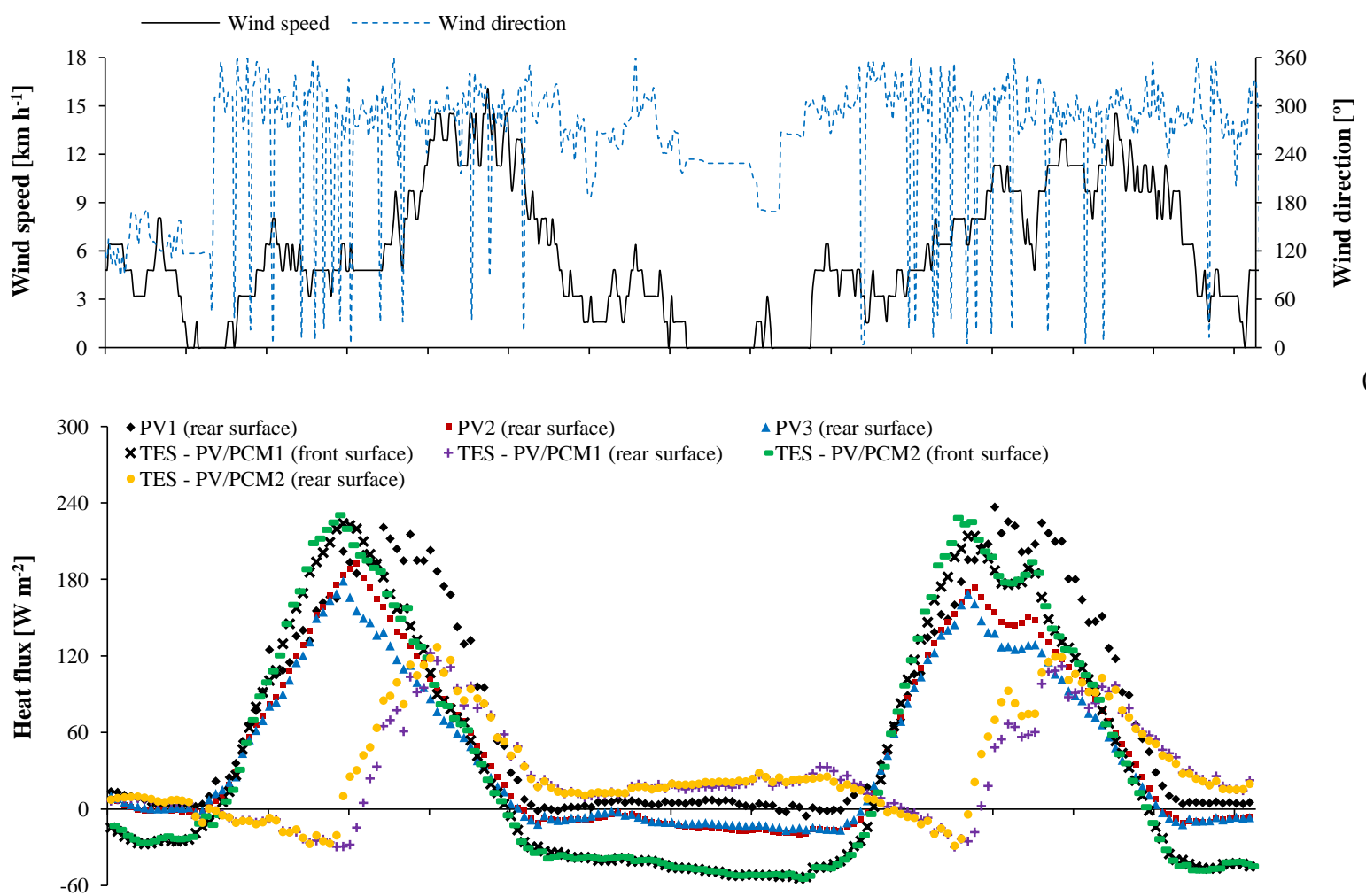

(a)

(b)

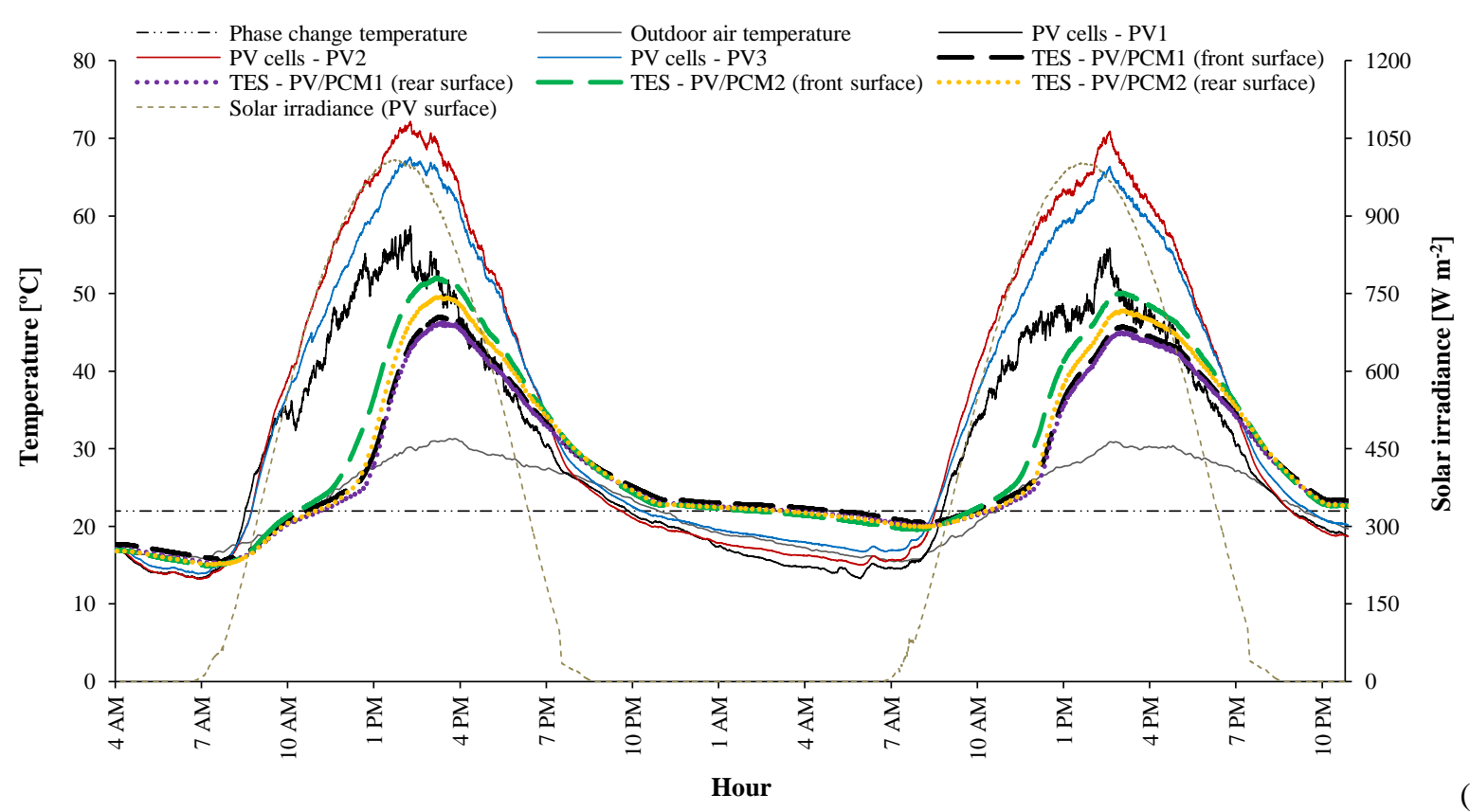

(c)

Fig. 15. (a) Trends of the main climatic parameters measured in Coimbra, $14^{\text {th }}$ and $15^{\text {th }}$ August, 2018. (b) Time evolutions of the heat flux measured at the rear surfaces of the PV panels and at the front and back surfaces of the TES units during the same short-term summer period. (c) Time evolutions of the temperature of the PV cells and of the temperatures measured at the front and rear surfaces of the TES units. The horizontal dashed line indicates the meltingpeak temperature of the PCM RT $22 \mathrm{HC}$ as provided by the manufacturer. 
In an ideal PV/PCM assembly, the PV panel would be perfectly in touch with the TES unit since this thermal contact would improve the heat transfer between the rear surface of the PV panel and the heat storage device. However, the presence of a thin air-layer in-between the PV panel and the TES unit in the experimental PV/PCM assembly (to accommodate the wires of the sensors and some warping of the TES unit) will add a spurious thermal resistance that will originate this discrepancy. The influence of this thermal contact resistance is even more evident when comparing the time evolutions of the measured temperatures. As shown in Fig. 15c, the temperature in the front surfaces of the TES units starts increasing only after ca. 1 PM. Before that moment, the temperature remains roughly anchored at the level of the phase change temperature of the PCM ( $c a$. $22{ }^{\circ} \mathrm{C}$ ), which means that the PCM is then playing the desired thermoregulation role. Moreover, the results show that the maximum temperatures recorded in the front surfaces of the TES units are lower than the maximum temperature measured in the PV cells of the reference PV1, which, in turn, is much lower than those measured in the PV2 and PV3 cells. Therefore, these results evidence that the thin air-layer in-between the PV panels and the TES units is playing a major detrimental role in the experiments and in the overall performance of the PV panels of the PV/PCM systems. This problem must be taken into account in future simulations and in the optimization of the PV/PCM assemblies in upcoming studies. In fact, it is expected that the thermal regulation period would be increased by considering a PCM with a higher phase change temperature, but it is even more expected that the overall performance of the PV/PCM systems would be significantly improved if the thermal contact resistance could be minimized. This can be easily achieved in future numerical simulations, but it is very hard to attain in experimental assemblies.

The results also show a greater uniformity of temperature distribution on the front and rear surfaces of the TES unit of the PV/PCM 1 system (with horizontally oriented cavities). This trend is caused by the influence of natural convection in the molten PCM, which is more evident in the vertically oriented cavities arrangement $\left(\mathrm{PV} / \mathrm{PCM}_{2}\right)$, that must be considered in future numerical simulations. Natural convection in the melted PCM also increases the heat flux on the rear surface of the TES unit of the PV/PCM ${ }_{2}$ system, as shown in Fig. 15b (after the end of the melting phase of the PCM, ca. 1 PM). Finally, the time evolutions of the heat flux on the rear surfaces of the TES units show that between 8.30 AM and 1 PM the heat flux is negative, as the heat is being stored in the TES unit (the PCM is melting). After this period, the heat flux is positive due to wind cooling in the rear surfaces of the TES units. During the night the heat flux is also positive (outwards), which means that the heat stored during the day is being discharged (the PCM is solidifying). However, at 7 AM, when the outdoor air temperature is lower and insolation starts, this heat flux achieves a maximum of $c a .30 \mathrm{~W} \mathrm{~m}^{-2}$, which may suggest that the PCM is not fully solidified when a new 
charging cycle starts.

\section{Summary and conclusions}

This paper provided an overview of previous studies that have used PCMs for the passive thermal regulation of PV devices. It also described a new real-scale outdoor experimental apparatus developed to assess the performance of new PV/PCM systems. Some preliminary experiments were carried out: $(i)$ measurement of the main thermophysical properties of the PCM used; (ii) evaluation of the reliability of directly measuring the solar irradiance on the PV panels' plane with the Kipp\&Zonen CM11 pyranometer; (iii) analysis of the main electrical characteristics of the PV panels; and (iv) assessment of the consistency of the energy generated by the three PV modules under the same climatic conditions. Based on the preliminary results, it was concluded that $(i)$ it is critical to measure the main thermophysical properties of the PCM used in the experiments in order to provide reliable data that can be used in future numerical simulations, as some of these properties are different from those provided by the commercial datasheet of the material; (ii) the main characteristic parameters of the three PV modules were consistent with each other, and with the parameters provided by the supplier; (iii) there was a good uniformity in the energy generated by each PV module, with a maximum deviation of $c a .4 \%$ in relation to the energy generated by the PV1 panel taken as reference.

The time evolutions of the temperature of the PV panels were compared with each other to assess the thermal regulation potential of the TES units. The time evolution of the power output was also evaluated to compare the efficiency of the different systems. It was concluded that the movable TES units filled with the PCM RT $22 \mathrm{HC}$ have a negative impact on the performance of the two PV/PCM systems during the summer conditions under evaluation since: $(i)$ the PV operating temperature has increased $c a \cdot 16-21^{\circ} \mathrm{C}$ and $14-18{ }^{\circ} \mathrm{C}$ in the $\mathrm{PV} / \mathrm{PCM}_{1}$ and $\mathrm{PV} / \mathrm{PCM}_{2}$ systems, respectively, in comparison with the $\mathrm{PV}_{\text {ref }}$ (at peak time), and (ii) the daily energy produced by the $\mathrm{PV}$ panel of the PV/PCM 1 and $\mathrm{PV} / \mathrm{PCM}_{2}$ systems was, respectively, 3.3-6.5\% and 3.3-6.0\% lower than that produced by the $\mathrm{PV}_{\text {ref. }}$ It was also concluded that $(i)$ a PCM with a higher phase change temperature must be chosen to fill-up the movable TES units in order to increase the thermal regulation period of the PV cells and to reduce the temperature rise in the PV cells of the PV/PCM systems during the peak hours; (ii) ideally, the air-layer in-between the PV panel and the movable TES unit should be removed (which is very difficult to achieve in home-made experimental apparatus), or the thermal resistance of this air-layer must be reduced in order to improve the thermal regulation effect of the PV cells; (iii) TES units with vertically oriented cavities seem to be more efficient, as the effect of natural convection in the molten PCM will be increased, thus 
reducing the temperature rise in the PV cells of the PV/PCM systems during the peak hours; (iv) the configuration of the metallic containers of the TES units should be improved to enhance wind cooling of the TES unit during the peak period (as well as during the night).

Although some of these conclusions contradict the results reported in other previous works listed in the literature review section of this paper, and thus may frustrate the use of this particular PCM to shave the peak temperature of the PV panels of the proposed PV/PCM systems with movable TES units, the obtained results can be easily replicated and used for future numerical validation purposes. The validated numerical models can then be used to optimize the configuration of the PV/PCM system in a faster and cheaper way, for different climates and considering different PCMs with other thermophysical properties.

\section{Acknowledgements}

The authors thank Mr. José Mário Soares for his help in the production of the metallic containers to be used in the TES units. They also thank Vera Lourenço and Francisco Nunes for their help during the implementation of the experiments. They would also like to acknowledge the Technological Centre of Ceramics and Glass (CTCV) for providing the PVPM2540C mobile peak power measuring device and $I-V$ curve tracer for PV modules, and the company SunEnergy ${ }^{\circledR}$ for providing the PV panels used in the experiments. This work was supported by FEDER funds through COMPETE 2020 - POCI, and by FCT in the framework of the project PCMs4Buildings (POCI-01-0145-FEDER-016750 | PTDC/EMSENE/6079/2014).

\section{COMPETE $20202020 \quad$ FCT}

\section{Nomenclature}

A $\quad$ area of the PV panel $\left[\mathrm{m}^{2}\right]$

$c_{\text {eff }} \quad$ effective specific heat $\left[\mathrm{J} \mathrm{kg}^{-1} \mathrm{~K}^{-1}\right]$

$c_{\mathrm{p}} \quad$ specific heat $\left[\mathrm{J} \mathrm{kg}^{-1} \mathrm{~K}^{-1}\right]$

$E \quad$ electricity generated by a PV panel per day $\left[\mathrm{kWh}^{-1}\right.$ day $\left.^{-1}\right]$

FF fill factor [ ]

$G_{\mathrm{PVPM}} \quad$ solar irradiance measured with the PVPM2540C mobile device [W m ${ }^{-2}$ ]

$G_{\text {pyra }} \quad$ solar irradiance measured with the Kipp\&Zonen CM11 pyranometer [W $\mathrm{m}^{-2}$ ]

$G_{\mathrm{ws}} \quad$ solar irradiance measured with the Davis Instruments Vantage Pro $2^{\mathrm{TM}}$ weather station [W $\mathrm{m}^{-2}$ ]

I current [A]

$I_{\mathrm{MPP}} \quad$ maximum power current $[\mathrm{A}]$

$I_{\mathrm{SC}} \quad$ short circuit current $[\mathrm{A}]$

$k$ thermal conductivity $\left[\mathrm{W} \mathrm{m}^{-1} \mathrm{~K}^{-1}\right.$ ]

$L_{\mathrm{m}} \quad$ latent heat of fusion $\left[\mathrm{kJ} \mathrm{kg}^{-1}\right]$

$L_{\mathrm{s}} \quad$ latent heat of solidification $\left[\mathrm{kJ} \mathrm{kg}^{-1}\right]$

$P_{\mathrm{PV}} \quad$ PV power output [W]

$P_{\mathrm{MPP}} \quad$ maximum power [W]

$P_{\mathrm{pk}} \quad$ peak power [W]

$T \quad$ temperature $\left[{ }^{\circ} \mathrm{C}\right]$

$T_{\mathrm{m}} \quad$ melting-peak temperature of the PCM $\left[{ }^{\circ} \mathrm{C}\right]$ 


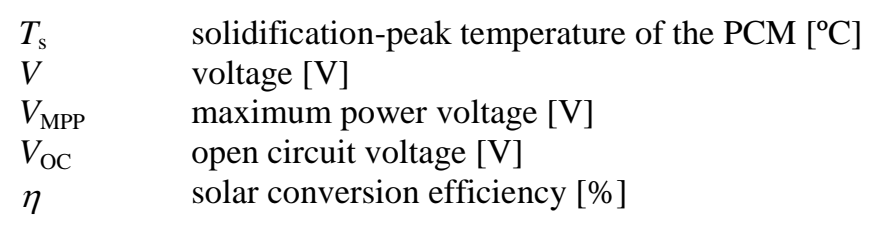

Abbreviations

$\begin{array}{ll}\text { MDSC } & \text { modulated differential scanning calorimetry } \\ \text { MPP } & \text { maximum power point } \\ \text { PCM } & \text { phase change material } \\ \text { PV } & \text { photovoltaic } \\ \text { STC } & \text { standard test conditions } \\ \text { TES } & \text { thermal energy storage } \\ \text { TPS } & \text { transient plane source }\end{array}$

\section{References}

[1] International Renewable Energy Agency, “Trends in Renewable Energy (Installed Capacity)," 2018. [Online]. Available: http://resourceirena.irena.org/gateway/dashboard/?topic=4\&subTopic $=16$. [Accessed: 15-Jul-2018].

[2] N. Soares et al., "The challenging paradigm of interrelated energy systems towards a more sustainable future," Renewable and Sustainable Energy Reviews, vol. 95, pp. 171-193, 2018.

[3] T. M. Sathe and A. S. Dhoble, "A review on recent advancements in photovoltaic thermal techniques," Renewable and Sustainable Energy Reviews, vol. 76, pp. 645-672, 2017.

[4] A. Shukla, K. Kant, A. Sharma, and P. H. Biwole, "Cooling methodologies of photovoltaic module for enhancing electrical efficiency: A review," Solar Energy Materials and Solar Cells, vol. 160, pp. 275-286, 2017.

[5] A. Makki, S. Omer, and H. Sabir, "Advancements in hybrid photovoltaic systems for enhanced solar cells performance," Renewable and Sustainable Energy Reviews, vol. 41, pp. 658-684, 2015.

[6] A. H. A. Al-Waeli, K. Sopian, H. A. Kazem, and M. T. Chaichan, "Photovoltaic/Thermal (PV/ T) systems: Status and future prospects," Renewable and Sustainable Energy Reviews, vol. 77, pp. 109130, 2017.

[7] M. Chandrasekar, S. Rajkumar, and D. Valavan, "A review on the thermal regulation techniques for non integrated flat PV modules mounted on building top," Energy \& Buildings, vol. 86, pp. 692-697, 2015.

[8] D. Du, J. Darkwa, and G. Kokogiannakis, "Thermal management systems for Photovoltaics (PV) installations: A critical review," Solar Energy, vol. 97, pp. 238-254, Nov. 2013.

[9] S. Sargunanathan, A. Elango, and S. T. Mohideen, "Performance enhancement of solar photovoltaic cells using effective cooling methods : A review," Renewable and Sustainable Energy Reviews, vol. 64, pp. 382-393, 2016.

[10] H. M. S. Bahaidarah, A. A. B. Baloch, and P. Gandhidasan, "Uniform cooling of photovoltaic panels: A review," Renewable and Sustainable Energy Reviews, vol. 57, pp. 1520-1544, 2016. 
[11] T. Ma, H. Yang, Y. Zhang, L. Lu, and X. Wang, "Using phase change materials in photovoltaic systems for thermal regulation and electrical efficiency improvement: A review and outlook," Renewable and Sustainable Energy Reviews, vol. 43, pp. 1273-1284, 2015.

[12] M. C. Browne, B. Norton, and S. J. Mccormack, "Phase change materials for photovoltaic thermal management," Renewable and Sustainable Energy Reviews, vol. 47, pp. 762-782, 2015.

[13] S. Nižetić, A. M. Papadopoulos, and E. Giama, "Comprehensive analysis and general economicenvironmental evaluation of cooling techniques for photovoltaic panels, Part I: Passive cooling techniques," Energy Conversion and Management, vol. 149, pp. 334-354, 2017.

[14] L. Navarro et al., "Thermal energy storage in building integrated thermal systems: A review. Part 2. Integration as passive system," Renewable Energy, vol. 85, pp. 1334-1356, 2016.

[15] S. S. Chandel and T. Agarwal, "Review of cooling techniques using phase change materials for enhancing efficiency of photovoltaic power systems," Renewable and Sustainable Energy Reviews, vol. 73, pp. 1342-1351, 2017.

[16] Z. Ling et al., "Review on thermal management systems using phase change materials for electronic components, Li-ion batteries and photovoltaic modules," Renewable and Sustainable Energy Reviews, vol. 31, pp. 427-438, 2014.

[17] M. M. Islam, A. K. Pandey, M. Hasanuzzaman, and N. A. Rahim, "Recent progresses and achievements in photovoltaic-phase change material technology: A review with special treatment on photovoltaic thermal-phase change material systems," Energy Conversion and Management, vol. 126, pp. 177-204, 2016.

[18] T. R. Shah and H. M. Ali, "Applications of hybrid nanofluids in solar energy, practical limitations and challenges: A critical review," Solar Energy, vol. 183, pp. 173-203, 2019.

[19] M. J. Huang, "The effect of using two PCMs on the thermal regulation performance of BIPV systems," Solar Energy Materials and Solar Cells, vol. 95, pp. 957-963, 2011.

[20] J. H. C. Hendricks and W. G. J. H. M. van Sark, "Annual performance enhancement of building integrated photovoltaic modules by applying phase change materials," Prog. Photovolt: Res. Appl., vol. 21, pp. 620-630, 2013.

[21] N. Soares, J. J. Costa, A. R. Gaspar, and P. Santos, "Review of passive PCM latent heat thermal energy storage systems towards buildings' energy efficiency," Energy and Buildings, vol. 59, pp. 82$103,2013$.

[22] Z. A. Qureshi, H. M. Ali, and S. Khushnood, "Recent advances on thermal conductivity enhancement of phase change materials for energy storage system: A review," International Journal of Heat and Mass Transfer, vol. 127, pp. 838-856, 2018.

[23] N. Soares, A. R. Gaspar, P. Santos, and J. J. Costa, "Experimental study of the heat transfer through a vertical stack of rectangular cavities filled with phase change materials," Applied Energy, vol. 142, pp. 192-205, 2015.

[24] N. Soares, A. R. Gaspar, P. Santos, and J. J. Costa, "Experimental evaluation of the heat transfer through small PCM-based thermal energy storage units for building applications," Energy and Buildings, vol. 116, pp. 18-34, 2016. 
[25] N. Soares, "Thermal energy storage with Phase Change Materials (PCMs) for the improvement of the energy performance of buildings," PhD Dissertation in Sustainable Energy Systems. Department of Mechanical Engineering of the Faculty of Sciences and Technology of the University of Coimbra, Coimbra, Portugal, 2015.

[26] T. Silva, R. Vicente, N. Soares, and V. Ferreira, "Experimental testing and numerical modelling of masonry wall solution with PCM incorporation: A passive construction solution," Energy and Buildings, vol. 49, pp. 235-245, 2012.

[27] R. Vicente and T. Silva, "Brick masonry walls with PCM macrocapsules: An experimental approach," Applied Thermal Engineering, vol. 67, pp. 24-34, 2014.

[28] N. Soares, J. J. Costa, A. Samagaio, and R. Vicente, "Numerical evaluation of a phase change material-shutter using solar energy for winter nighttime indoor heating," Journal of Building Physics, vol. 37, no. 4, pp. 367-394, Jul. 2014.

[29] M. J. Huang, P. C. Eames, and B. Norton, "Thermal regulation of building-integrated photovoltaics using phase change materials," International Journal of Heat and Mass Transfer, vol. 47, pp. 27152733, Jun. 2004.

[30] M. J. Huang, P. C. Eames, and B. Norton, "Phase change materials for limiting temperature rise in building integrated photovoltaics," Solar Energy, vol. 80, pp. 1121-1130, 2006.

[31] M. J. Huang, P. C. Eames, B. Norton, and N. J. Hewitt, "Natural convection in an internally finned phase change material heat sink for the thermal management of photovoltaics," Solar Energy Materials and Solar Cells, vol. 95, pp. 1598-1603, 2011.

[32] P. H. Biwole, P. Eclache, and F. Kuznik, "Phase-change materials to improve solar panel's performance," Energy and Buildings, vol. 62, pp. 59-67, Jul. 2013.

[33] T.-ur- Rehman, H. M. Ali, A. Saieed, W. Pao, and M. Ali, "Copper foam/PCMs based heat sinks: An experimental study for electronic cooling systems," International Journal of Heat and Mass Transfer, vol. 127, pp. 381-393, 2018.

[34] H. M. Ali, A. Arshad, M. Jabbal, and P. G. Verdin, "Thermal management of electronics devices with PCMs filled pin-fin heat sinks: A comparison," International Journal of Heat and Mass Transfer, vol. 117, pp. 1199-1204, 2018.

[35] A. Arshad, H. M. Ali, M. Ali, and S. Manzoor, "Thermal performance of phase change material (PCM) based pin-finned heat sinks for electronics devices: Effect of pin thickness and PCM volume fraction," Applied Thermal Engineering, vol. 112, pp. 143-155, 2017.

[36] H. M. Ali et al., "Thermal management of electronics: An experimental analysis of triangular, rectangular and circular pin-fin heat sinks for various PCMs," International Journal of Heat and Mass Transfer, vol. 123, pp. 272-284, 2018.

[37] S. Preet, B. Bhushan, and T. Mahajan, "Experimental investigation of water based photovoltaic/thermal (PV/T) system with and without phase change material (PCM)," Solar Energy, vol. 155, pp. 1104-1120, 2017.

[38] M. C. Browne, K. Lawlor, A. Kelly, B. Norton, and S. J. Mccormack, "Indoor characterisation of a photovoltaic/thermal phase change material system," Energy Procedia, vol. 70, pp. 163-171, 2015. 
[39] M. C. Browne et al., "Assessing the thermal performance of phase change material in a photovoltaic/thermal system," Energy Procedia, vol. 91, pp. 113-121, 2016.

[40] M. C. Browne, B. Norton, and S. J. McCormack, "Heat retention of a photovoltaic/thermal collector with PCM,” Solar Energy, vol. 133, pp. 533-548, 2016.

[41] C. J. Smith, P. M. Forster, and R. Crook, "Global analysis of photovoltaic energy output enhanced by phase change material cooling," Applied Energy, vol. 126, pp. 21-28, 2014.

[42] M. J. Huang, P. C. Eames, and B. Norton, "Comparison of a small-scale 3D PCM thermal control model with a validated 2D PCM thermal control model," Solar Energy Materials and Solar Cells, vol. 90, pp. 1961-1972, 2006.

[43] A. Hasan, S. J. McCormack, M. J. Huang, and B. Norton, "Evaluation of phase change materials for thermal regulation enhancement of building integrated photovoltaics," Solar Energy, vol. 84, pp. $1601-1612,2010$.

[44] A. Hasan, S. J. McCormack, M. J. Huang, J. Sarwar, and B. Norton, "Increased photovoltaic performance through temperature regulation by phase change materials: Materials comparison in different climates," Solar Energy, vol. 115, pp. 264-276, 2015.

[45] A. Hasan, S. J. McCormack, M. J. Huang, and B. Norton, "Energy and cost saving of a photovoltaicphase change materials (PV-PCM) system through temperature regulation and performance enhancement of photovoltaics," Energies, vol. 7, pp. 1318-1331, 2014.

[46] A. Hasan, J. Sarwar, H. Alnoman, and S. Abdelbaqi, "Yearly energy performance of a photovoltaicphase change material (PV-PCM) system in hot climate," Solar Energy, vol. 146, pp. 417-429, 2017.

[47] A. Hasan, H. Alnoman, and Y. Rashid, "Impact of integrated photovoltaic-phase change material system on building energy efficiency in hot climate," Energy \& Buildings, vol. 130, pp. 495-505, 2016.

[48] F. Hachem, B. Abdulhay, M. Ramadan, H. El Hage, M. G. El Rab, and M. Khaled, "Improving the performance of photovoltaic cells using pure and combined phase change materials - Experiments and transient energy balance," Renewable Energy, vol. 107, pp. 567-575, 2017.

[49] R. Stropnik and U. Stritih, "Increasing the efficiency of PV panel with the use of PCM," Renewable Energy, vol. 97, pp. 671-679, 2016.

[50] L. Tan, A. Date, G. Fernandes, B. Singh, and S. Ganguly, "Efficiency gains of photovoltaic system using latent heat thermal energy storage," Energy Procedia, vol. 110, pp. 83-88, 2017.

[51] G. Ciulla, V. Lo Brano, M. Cellura, V. Franzitta, and D. Milone, "A finite difference model of a PVPCM system," Energy Procedia, vol. 30, pp. 198-206, 2012.

[52] V. Lo Brano, G. Ciulla, A. Piacentino, and F. Cardona, "On the efficacy of PCM to shave peak temperature of crystalline photovoltaic panels: An FDM model and field validation," Energies, vol. 6, pp. 6188-6210, 2013.

[53] V. Lo Brano, G. Ciulla, A. Piacentino, and F. Cardona, "Finite difference thermal model of a latent heat storage system coupled with a photovoltaic device: Description and experimental validation," Renewable Energy, vol. 68, pp. 181-193, 2014. 
[54] M. A. Kibria, R. Saidur, F. A. Al-Sulaiman, and M. M. A. Aziz, "Development of a thermal model for a hybrid photovoltaic module and phase change materials storage integrated in buildings," Solar Energy, vol. 124, pp. 114-123, 2016.

[55] K. Kant, A. Shukla, A. Sharma, and P. H. Biwole, "Heat transfer studies of photovoltaic panel coupled with phase change material," Solar Energy, vol. 140, pp. 151-161, 2016.

[56] RT 22 HC Rubitherm Gmbh, "RT 22 HC data sheet," 2016. [Online]. Available: https://www.rubitherm.eu/media/products/datasheets/Techdata_-RT22HC_EN_06082018.PDF. [Accessed: 19-Mar-2019].

[57] J. C. Gonçalves, J. J. Costa, A. R. Figueiredo, and A. M. G. Lopes, "Study of the aerodynamic sealing of a cold store - Experimental and numerical approaches," Energy and Buildings, vol. 55, pp. 779$789,2012$.

[58] Risen solar technology, "Risen $250 \mathrm{~W}$ data sheet." [Online]. Available: http://temp.winsolarwholesale.com.au/wpcontent/uploads/2018/03/Risen_ProductDatasheet_RSM60-6-250P-270P-4BB_IEC1000VdcEnglish.pdf. [Accessed: 19-Mar-2019].

[59] Davis Instruments Vantage Pro2, “ADAI@DEM.UC Station.” [Online]. Available: https://www.wunderground.com/hourly/pt/coimbra/ICOIMBRA14. [Accessed: 19-Mar-2019].

[60] J. Fořt, Z. Pavlík, A. Trník, M. Pavlíková, and R. Černý, "Effect of the mode and dynamics of thermal processes on DSC-acquired phase-change temperature and latent heat of different kinds of PCM," Materials and technology, vol. 51, no. 6, pp. 919-924, 2017. 